\title{
Grégoire Espesset*
}

\section{The Invention of Buddho-Taoism: Critical Historiography of a Western Neologism, 1940s-2010s}

\author{
https://doi.org/10.1515/asia-2016-0061
}

\begin{abstract}
Buddho-Taoism" is a neologism that appeared in Western academic writings during the late nineteen-forties, was put to various uses without ever being consensually defined, enjoyed a brief vogue around the turn of the twentyfirst century, and began to fall from grace in recent years. Not only did this neologism implicitly create new epistemic repertoires derived from the names of two presumably known religions. Increasingly loaded with a heterogeneous subtext pertaining to Western-centred representations of the non-European Other, it has become a highly versatile speech unit. By contextualising the appearance of "Buddho-Taoism" and its attested variants in European-language writings and following their semantic evolution, this essay attempts to shed light on some of the problems raised by its retrospective implementation in contemporary Western discourse on China. It also illustrates the power of seduction of trendy terms that academics tend to overuse without careful consideration for their meaning, thereby adding unnecessary problems to the intrinsic difficulties of their primary materials.
\end{abstract}

Keywords: Sinology, historiography, hermeneutics, Chinese Buddhism, Taoism (Daoism)

This is the historiography of a term that appeared in Western academic writings during the late nineteen-forties, was put to various uses without ever being consensually defined, enjoyed a brief vogue around the turn of the twenty-first century, and began to fall from grace in recent years. This term is the substantive "Buddho-Taoism" and the related form "Buddho-Taoist", either as an adjective (as in "Buddho-Taoist interaction") or, for persons, a substantive ("the Buddho-Taoists"). ${ }^{1}$ The spread of this neologism in writings

1 The two forms also appear under the spelling "Buddho-Daoism" and "Buddho-Daoist" (see n. 8). Quotations from secondary sources in this paper reproduce original spellings.

*Corresponding author: Grégoire Espesset, Independent scholar, Paris, France.

E-mail: gresp@yahoo.com 
primarily in English, but also in other European languages, has impacted social, intellectual and religious history, epigraphy, and iconography, in the fields of Chinese and East Asian studies. Beyond this particular case, this paper also illustrates the power of seduction of trendy terms that we academics tend to overuse without careful consideration for their meaning, thereby adding unnecessary problems and layers of interpretation to the intrinsic difficulties of our primary materials. ${ }^{2}$

\section{Prologue: "Taoism" and "(Chinese) Buddhism"}

To circumscribe in as few words as possible the complex relationship between China's two major religious groups is no easy task and bound to produce a simplistic result. As any social entity striving for popular following and official support, both had to maximise their attractiveness while downplaying competition. The earliest Central Asian Buddhists who began missionary work in the Empire in the first or second century of our era needed their authoritative scriptural sources - the sutras - to be adapted into Chinese, but also to show that Buddhist dogmas did not endanger Chinese social order by subverting its core values. As the new faith spread, some upholders of indigenous worldviews and practices - scattered "ways" (tao 道) far from forming the unified entity that we call "Taoism" - tried to reduce it to a foreign, lower form of their own traditions. This strategy having failed, religious communities partaking of a more or less common cultural heritage had to share with Buddhists the sphere of mass religion in China from the early medieval era on. ${ }^{3}$ Only recently did scholars begin to get a more comprehensive picture of how these groups coexisted and of their multifarious interplay, including competition and

\footnotetext{
2 In this paper, "Orientalist", "Buddhologist" and "Sinologist" are used for the sake of convenience and do not imply on my part any endorsement of their ideological subtext in Westerncentred representations of otherness. They function as shorter equivalents of, respectively, "Western scholar specialist of the Orient (in the broadest classical sense)"; "scholar specialist of Buddhism in whatever cultural, historical and linguistic context"; and "scholar specialist of China". My use of "China" is strictly conventional; over time, the polity thus called constantly changed in geographical extension and, despite state centralisation and the development of Han nationalism, has always remained a mosaic of regional and local cultures.

3 Borrowing from European terminology, historians of China now distinguish an early medieval era - first, second or third to sixth centuries - and a medieval era ending in the thirteenth or fourteenth century or later. The definition of these eras and their relevance to Chinese history remain debated.
} 
controversy, but also various levels and modes of cooperation, exchange and mutual emulation. ${ }^{4}$

For Westerners, the linguistic gap adds to the diachronic and cultural distance, rendering even more problematic any attempt to describe nonEuropean manifestations of religiosity in history. The earliest Western mention of Taoism and Buddhism in China may be ascribed to the Jesuit Mateo Ricci (1552-1610) in his De Christiana expeditione apud Sinas, as Nicholas Trigault (1577-1628), another Jesuit, titled his Latin translation of Ricci's unfinished manuscript in Italian. Ricci/Trigault, instead of using the "-isms" that are familiar to us, named both "sects" (sectae) after their founders, "Sciequia” and “Lauzu”, presumably Shih-chia 釋迦 (Sākya, the name of Buddha's clan, short for Śākyamuni) and Lao-tzŭ 老子 (the Old Master) respectively. ${ }^{5}$ It is unclear exactly when and where the forms "Taoism" and "Buddhism" were coined, but the Oxford English Dictionary, second edition (1989) gives the dates 1801 for "Buddhism" and 1838 for the early forms "Taouism" and "Taouist", now long in disuse. In time, some scholars have come to criticise the hermeneutical and heuristic value of these terms and the consequences of their usage, in particular reification and essentialism. ${ }^{6}$ As an early example, the renowned Dutch Sinologist Erik Zürcher (1928-2008) wrote: "What we call 'Chinese Buddhism' and 'Taoism' are, after all, abstractions, created by the fact that they only show themselves to us at the top level, that of the clerical establishments who created and maintained the two great traditions."7 A recent North American trend of using the variant "Daoism" has only blurred an already unclear picture, especially to the non-specialist audience. ${ }^{8}$

4 In addition to references in further footnotes, see, among others, Robinet 1984; Bokenkamp 2001; Robinet 2004; Raz 2014; Plassen 2015. For published bibliographical surveys, see n. 111 below.

5 See Ricci 1615: 105 (“Sciequia”), 112 (“Lauzu”). How Trigault retrieved Ricci's manuscript, then edited and translated it, is covered in Mungello 1985: 46-49.

6 See Campany 2003; Barrett 2010. For the particular case of Taoism, see Sivin 1978; Kirkland 2004: xii-xvii, 1-11; Raz 2004: 6-14; Sivin 2010.

7 Zürcher 1982b: 47.

8 Since the Wade-Giles Romanisation system and the spelling "Taoism" prevailed during the earlier decades of the period covered by my investigation, I use both in this paper. Michael Carr championed the later Pinyin (PRC's official Romanisation system) and the spelling "Daoism" in a paper (1990), which, as I wrote elsewhere, was flawed in many respects. In particular, "Taoism", unlike "kowtow", is not a "loanword" in the strict sense of the term (Carr 1990: 62); and the assertion that, "in most cases," Pinyin "more accurately represents Chinese pronunciation" than Wade-Giles (1990: 67-68) would need qualification. Transliterations are by nature arbitrary and imperfect, and imposing any new one is likely to provoke some confusion: the later spelling has lead some academics from various fields to wonder whether 
"Buddho-Taoism" and, to a lesser extent perhaps, "Buddho-Taoist" added to these problems by implicitly creating new epistemic repertoires derived from the names of two presumably known religions. But do these terms refer to the total sum of "Buddhism" and "Taoism", or to the product of the union of some of their parts, and, if so, which parts? To what historical era or eras and geographical area or areas may they be applied? And, equally importantly if not more, has any attested equivalent of these terms in the Chinese language ever existed and been used, self-referentially and self-consciously, by any social entity, be it an individual, group or institution? There does not seem to exist, at least in published form, a consensual definition of what "Buddho-Taoism" is supposed to mean. None of the existing encyclopaedic or lexicographic sources dealing primarily with Buddhism, Taoism or religion in the broadest sense, provides an entry for the substantive or simply defines it. ${ }^{9}$ Interestingly, however, the adjective forms "Buddhist-Taoist" and "Buddho-Taoist" appear in these works, albeit rarely. For example, Livia Kohn, in one of her own two chapters in the Daoism Handbook published under her editorship, states that Taoist monastic organisation under the Northern Dynasties (fifth-sixth centuries) "still shows a distinct Buddho-Daoist flavor". ${ }^{10}$ The formula conveys a feeling of redundancy - why not simply "a distinct Buddhist flavor"? As to the acclaimed Historical Companion to the so-called Taoist Canon (Tao-tsang 道藏), it contains ten occurrences or so - all adjectival - of the neologism that cover quite a wide semantic range. ${ }^{11}$ More remarkably, though each of the following two reference works displays the substantive form, none of them elaborates on the nature of the entity thus denoted. In the Encyclopedia of Taoism, Christine Mollier's entry on "Dunhuang manuscripts" asserts that "Dunhuang studies have also contributed much to research on medieval Buddho-Taoism" ${ }^{2}$; and John Lagerwey's

“Taoism" and "Daoism” refer to two different things (paraphrasing Espesset 2017: 34). Finally, in addition to being still current in English, the "T-" spelling remains standard in major European languages such as French, German, Dutch and Spanish.

9 These include, for Taoism, Kohn 2000; Schipper/Verellen 2004; Pregadio 2008. For Buddhism, Buswell 2004; Irons 2008. For religion, Jones 2005.

10 Kohn 2000: 303.

11 Schipper/Verellen 2004: 275 (a text as "perfect Buddho-Taoist hybrid"), 352 (the "BuddhoTaoist content and quasi-magical use" of another text), 420 ("Buddho-Taoist relations under the Tang and Five Dynasties"), 516 ("Buddho-Taoist thoughts and institutions"), 521 ("BuddhoTaoist debates"), 526 ("a new phase in Buddho-Taoist relations"), 686 ("Buddho-Taoist debates" again), 1185 ("the famous Buddho-Taoist controversies of the 1250s"), 1233 (another "BuddhoTaoist text”), 1341 ("Buddho-Taoist scriptures and iconography").

12 In Pregadio 2008: 393. Note also two adjectival occurrences: "the court-sponsored BuddhoTaoist debates of the fifth and sixth centuries" (663) and "the Buddho-Taoist debates at the northern courts" (710). 
"Introduction" to the state-of-the-field essays on early medieval Chinese religions published in Brill's "Handbook of Oriental Studies” series explains that certain Northern Dynasties steles "show Daoism - and Buddho-Daoism - taking up their places in an ecumenical whole". ${ }^{13}$ To sum up the awkwardness that transpires whenever that linguistic object appears in an author's mind, we may quote Paul Copp who, in a chapter from the recent Wiley-Blackwell Companion to Chinese Religions, evokes "the loose tradition that in recent years has come to be known (not entirely satisfactorily) as 'Buddho-Daoism"”. ${ }^{14}$

That, until recently, an international body of intellectuals often known for their critical verve felt compelled to emulate each other in using a signifier that lacks a clear signified and is loaded with a very fluctuating subtext, as we shall see, is enough to arouse intellectual curiosity. The result of such curiosity, this essay contextualises the appearance of "BuddhoTaoism" and its attested variants in Western writings and follows their semantic evolution in an attempt to shed light on some of the problems raised by its retrospective implementation in contemporary Western discourse on China. ${ }^{15}$ The method basically consists in a chronological examination of a number of occurrences collected from published secondary sources and a few dissertations. ${ }^{16}$

\section{Before "Buddho-Taoism"}

The renowned French Orientalist Henri Maspero (1883-1945) may well be responsible for the earliest syntactical combination of the terms "Buddhism" and "Taoism". In a paper published in 1934, Maspero twice characterised the religion of the community of Central Asian missionaries and their local converts attested in the city of Loyang (in present-day Honan Province,

13 Lagerwey/Lü 2010: 15. For problematic interpretations of stele inscriptions and their modern classification, see section 7 below.

14 Copp 2012: 96.

15 In addition to the English forms already mentioned, some of their attested equivalents in German and French are also taken into consideration.

16 This method has three inherent limitations. First, a discrepancy usually exists between explicit and actual publication dates; some known cases are noted below. Second, before its eventual appearance in print, a neologism may have been used informally, either orally or in private correspondence, and in unpublished materials such as drafts and communications. Third, I may have overlooked some secondary sources. Nevertheless, the amount of items analysed allows a coherent historiographical picture to emerge. 
China) during the first centuries of our era as exemplifying a form of "taoïsme bouddhisant", a French phrase more or less equivalent to "Buddhistic Taoism" in English. ${ }^{17}$ Grammatically, we are still dealing at this early stage with two detached words - a substantive and a present participle - and yet, whatever Maspero exactly had in mind, the idea was already there of the mixing, to an unspecified degree, of two religions supposed to be familiar to the reader: Taoism and, as a modifier, Buddhism.

Joined occurrences of the adjectival forms "Buddhist" and "Taoist" appeared in print during the mid-nineteen-forties at latest. Ironically perhaps, the feat is to be ascribed to a Chinese-American scholar, the Buddhologist Kenneth Kuan Shêng Ch'en 陳觀勝 (1907-1993). In his 1945 study of the thirteenth-century Illustrations of the Eighty-One Transformations (Pa-shih-ihua t’u八十一化圖), an account of the successive manifestations of Lao-tzŭ, Ch'en famously evoked "the problem of Buddhist-Taoist mixtures" arisen from the Taoist contention that the famous pre-imperial figure travelled to the West, where he transformed into the Buddha and founded a religion that was merely a lower form of Taoism adapted to Central Asians, as we have seen. ${ }^{18}$ Ch'en used again his twin adjectival form, for instance in the opening page of a 1956 paper mentioning the "Buddhist-Taoist controversy" that, together with economic motives, led to the great persecution of Buddhism in $845 .{ }^{19}$ In his book Buddhism in China (1964), the twin adjectival form served many purposes, in such phrases as "Buddhist-Taoist relations", "Buddhist-Taoist debates", "Buddhist-Taoist struggle", "Buddhist-Taoist controversy" and "Buddhist-Taoist mixtures" again. ${ }^{20}$ These examples suggest that, semantically, Ch'en's twin adjectival form retained a dual identity - a terminology common to some Buddhist and some Taoist texts, debates between Buddhists and Taoists, and so forth - even though he once defined "Buddhist-Taoist relations" during the Latter Han 後漢 dynasty (25-220) as an "alliance" of two "systems" that contemporary Chinese "regarded as one". ${ }^{21}$ This later view certainly acknowledged the impact of some of Liebenthal's intervening publications.

\footnotetext{
17 Maspero 1934: 91, 107.

18 Ch'en 1945. The polemical portrayal of Buddhism as a lower, localised offshoot of Taoism goes back to a narrative that was rooted in earlier official historiography; see Graham 1986.

19 Ch'en 1956: 67.

20 Ch'en 1964: 48, 53, 151, 421, 439, 541.

21 Ch'en 1964: 53.
} 


\section{Liebenthal's coining}

A dramatic shift happened when "Buddho-Taoist" and "Buddho-Taoism" started their career in the writings of a German-born Sinologist specialised into Chinese Buddhism, Walter Liebenthal (1886-1982). In the first edition of his study and translation of Chao's Treatises (Chao-lun 肇論) under the title The Book of Chao (1948), Liebenthal suspected an anonymous "Buddho-Taoist of the fifth century" to be the author of the Treasured Repository Treatise (Pao-tsang lun 寶藏論) ( $\mathrm{T}$ 45, no. 1857), ${ }^{22}$ traditionally ascribed to the monk Sêng-chao 僧肇 (384-414). He then evoked "Taoist and Buddho-Taoist literature" and went on to mention Hsüan-tsang 玄牀 (602-664), a monk, translator and pilgrim who “[conversed] with Taoist celebrities concerning the Buddho-Taoism of the early centuries", with a reference to a paper by the French Orientalist Paul Pelliot (1878-1945) where no equivalent of the neologism seems to be found. ${ }^{23}$ Perplexingly, nowhere in this book did Liebenthal define, even implicitly, what both forms of his neologism - the substantive and the adjective - were supposed to mean.

That meaning progressively took shape in Liebenthal's publications during the subsequent decade. In the opening section of a 1952 paper, he explained that "the gentlemen of Buddho-Taoist inclinations" were, with only few exceptions, "members of the gentry of more or less Buddhist or Taoist inclinations", mainly "officials", whilst "uneducated clerics who performed the ritual were in the fifth century looked down upon as common practitioners" and, therefore, not admitted in this aristocratic sphere. ${ }^{24}$ In a German paper published the same year, he added "Confucians" - the literates (ju 儒), keepers of official state ideology - to a still blurred picture. He wrote:

Es ist wichtig, zu betonen, daß die sich bekämpfenden Parteien nicht buddhistische und taoistische Kleriker waren, sondern Konfuzianer, mehr oder weniger skeptisch oder wundergläubig, zwischen Taoismus und Buddhismus nicht unterscheidend. Man könnte für diese Zeit etwas paradox von buddho-taoistischen Konfuzianer sprechen. [...] [Der] Buddho-Taoismus öffnete nur gleichsam eine tiefere, dem Volk nicht zugängliche Schicht der gleichen Offenbarung; er war esoterisch [...]..$^{25}$

22 Buddhist sources in Chinese are referenced according to their sequential numbering in the volumes (T) of the Japanese modern critical edition of the Buddhist Canon (Takakusu/Watanabe 1924-1934).

23 Liebenthal 1948: 11, 21, 41 (n. 128). I thank Olivier Venture for helping me access a copy of this now rare edition at the Bibliothèque de l'Institut des Hautes Études Chinoises, Paris, in December 2014. The French paper Liebenthal referred to is Pelliot 1912.

24 Liebenthal 1952a: 328-329.

25 Liebenthal 1952b: 116-120. The passage may translate as: "It is important to emphasise that the contending parties were not Buddhist and Taoist clerics, but Confucians, more or less 
To complicate the matter, a few years later, Liebenthal now defined as "BuddhoTaoists" a group of "neo-Taoist gentlemen, who later became Buddhists (Buddho-Taoists), were friendly with the literate monks and discussed Buddhist matters with them". ${ }^{26}$ It seems that Liebenthal increasingly used his coinage to denote early Chinese converts to Buddhism and their doctrine, for instance when discussing the law of causation. ${ }^{27}$ And yet in his study of the sixth-century "apocryphal" Treatise on the Arising of Faith [according to] the Major Vehicle (Ta-shêng ch’i-hsin lun 大乘起信論) (T 32, no. 1666), he explicitly included in his group of “Buddho-Taoists” Wang Pi 王腼 (226-249), a prominent representative of the "Learning of the Dark" and a renowned exegete of the Book of Changes (I-ching 易經), Lao-tzŭ, Chuang-tzŭ 莊子 and the Confucian Analects (Lun-yü 論語), but by no means a Buddhist convert. ${ }^{28}$

It became clear in subsequent publications that Liebenthal used his neologism as meaning simply "early Chinese Buddhism”. Consider, for instance, this quotation from a book review: “T’i [h stratum etc., and yung [用] may mean usage, application, function etc., but in neo-Taoism the couple t'i-yung is synonymous with pen-mo 本末, and in Buddho-Taoism it is equated with nirvāna-samsāra, i. e. two states, or eventually two aspects". ${ }^{29}$ This is confirmed by a short paper written before the publication of the second edition of his Book of Chao (1968). In that paper, he called the Chao-lun "a Buddho-Taoist work" and grouped under the category of "Buddho-

sceptical or believing in miracles, not distinguishing between Taoism and Buddhism. One could for this time, paradoxically somewhat, speak of Buddho-Taoist Confucians. [...] Buddho-Taoism only opened, so to speak, a deeper layer of the same revelation, which was not accessible to the people; it was esoteric [...]". For other mentions of "Buddho-Taoism" and "Buddho-Taoist mysticism”, yet without further elaboration, see Liebenthal 1954: 271, 273 (n. 1).

26 Liebenthal 1955: 61. In the same paper, Liebenthal wrote that "Confucian gentlemen of Buddho-Taoist inclinations" opposed "Confucian conservatives" (77) and again alluded to "gentlemen of Buddho-Taoist inclinations" and "Buddho-Taoist gentlemen" (78). In twentiethcentury Sinology, Paul Pelliot first called "Neo-Taoists" unspecified Taoists living in the second and third centuries; see Pelliot 1918/1919: 414-415 (n. 385). Later, Fung Yu-lan 馮友蘭 (18951990) and his translator Dirk Bodde (1909-2003) took up "Neo-Taoism" to describe the thirdand fourth-century trend known in Chinese as hsüan-hsüeh 玄學 ("Learning of the Dark"); see Fung 1948: 22, 211. At the turn of the nineteen-eighties, "Neo-Taoism" in this sense was criticised (see $\mathrm{n} .57$ below) and thenceforth seems to have fallen in disuse. It is conspicuously absent - as well as "Buddho-Taoism" - from Victor C. Xiong's Historical Dictionary of Medieval China (Xiong 2009).

27 Liebenthal 1956: 82 (n. 43) ("I am writing Karma when I refer to the Buddho-Taoist popular Karma of fatalistic masses, and karman when I refer to the Indian law of causation”).

28 Liebenthal 1958: 165.

29 Liebenthal 1960: 530. 
Taoist literature" or "Buddho-Taoist scriptures" a handful of early texts from the Chinese Buddhist Canon. ${ }^{30}$ In his "Preface to the second edition", Liebenthal acknowledged the fact that, during the intervening twenty years, "a number of studies [had] appeared on neo-Taoism and Buddho-Taoism and our knowledge of that period” - the centuries prior to the T'ang 唐 dynasty (618-907) - “[had] become much broader". ${ }^{31}$ He now referred to the Chinese Buddhist monks Huiyüan 慧元 (d. 389) and Chih Tun 支遁 (314-366) as “contemporary BuddhoTaoists" of Wang Pi, thereby apparently excluding the latter from the group, alluded to "the philosophically-minded Buddho-Taoists” in Sêng-chao's time, and defined "the goal of Buddho-Taoism" as being "the harmony with nature". 32

\section{3 "Buddho-Taoism" in the field of Buddhist studies}

Despite the contour of the neologism being originally nebulous, it was promptly adopted in their own work by some of Liebenthal's fellow Buddhologists. Perhaps is Leon Hurvitz (1923-1992) the earliest one to have done so, in a 1960 review of the reprint edition of an obscure book originally published in London in the late nineteen-twenties. Hurvitz deplored that "nothing, for example, [was] said about 'Buddho-Taoism' in early mediaeval China" in that book. ${ }^{33}$ Neither did he state what "Buddho-Taoism" was supposed to mean nor did he acknowledge whence the phrase came. Arthur Link (1920-1980) at first kept to Kenneth Ch'en's twin adjectival form in his paper on the "Buddhist-Taoist terminology” that the monk and scholar Tao-an 道安 (312-385) - the first organiser of Chinese Buddhist scriptures - used in his preface to the Parthian An Shih-kao's 安世高 (d. late 2nd/early 3rd cent.) translation of the Yogācārabhūmi-sūtra under the title Tao-ti ching 道地經 (T 15, no. 607). ${ }^{34}$ But, in a study jointly authored, Hurvitz and Link mentioned "Buddho-Taoist texts of

30 Liebenthal 1974: 200, 202, 203. Yves Hervouet (1921-1999) noted in the book's opening "avertissement" that all papers had been received in 1964-1965, but some could not be included in the first volume, then the publication of the second volume was delayed due to the Mai-1968 events in France.

31 Liebenthal 1968: xi.

32 Liebenthal 1968: 8, 33, 72 (n. 298).

33 Hurvitz 1960: 456. In his later review of Ch'en's Buddhism in China, however, he used only the adjectival form, in reference to hsüan-hsüeh (Hurvitz 1965: 449).

34 Link 1957. Tao-an's preface is preserved in Sêng-yu's 僧祐 (445-518) Collected Records [of Translations] from the Tripitaka (Ch'u san-tsang chi-chi 出三藏記集) (T 55, no. 2145), 10.69a-c. 
Tao-an's period" and an unspecified group of "Buddho-Taoists" including Taoan again, and found "Buddho-Taoist [capsules]" in Tao-an's prefaces. For Hurvitz and Link, the phrase ta-chih hsüan-t’ung 大智玄通 (“Great Wisdom's mysterious faculty of universal validity" in their "feeble attempt" to render it in English) "encapsulates Buddho-Taoism". ${ }^{35}$ The China-born American Sinologist and ordained Presbyterian minister Richard Mather (1913-2014), mainly known for his work on early medieval Chinese literature though his Ph.D. thesis concerned Buddhism, mentioned "the Buddho-Taoist intellectuals" of the Eastern Chin 東晉 dynasty (317-420) in a note on Chih Tun and Hui-yüan, both disciples of Tao-an. ${ }^{36}$

By the time the Canadian Richard Robinson (1926-1970) entered the scene of Buddhology, the forms "Buddhist-Taoist", "Buddho-Taoist" and "BuddhoTaoism" had all gained some currency. Robinson, however, apparently refrained from using the substantive form "Buddho-Taoism". In his book on Indian and Chinese Mādhyamika (chung-tao 中道), his mention of "the Buddho-Taoists on whom Liebenthal had already published some of his studies" concerned the fourth- and fifth-century Hui-yüan, Sêng-chao and the monk Sêng-jui 僧颅 (352436). Robinson deplored the lack of "an adequate lexicon of Buddho-Taoist vocabulary, which possesses a rich stock of formations that are unique to it". He found "Buddho-Taoist terms", or Chinese "technical terms used in translating Indian texts”, in some of Hui-yüan’s letters to the translator Kumārajivva 鳩摩 羅什 (344/367-409/413). For him, surviving writings by Sêng-jui "can be read as Six Dynasties essays, or as Buddhist tracts, as Neo-Taoist discourse, or as an incisive attack on Buddho-Taoist ideas", and many terms used by Sêng-chao have "specialised meanings not found in other Buddho-Taoist writings". 37

It is in his landmark Historical Introduction to Buddhism (1970) that Robinson may be credited with the earliest formulation of what may be seen as the first definition ever of the human group to be called "Buddho-Taoists":

The three generations of Chinese intellectual monks from Tao-an to Kumārajīva's disciples are called the Buddho-Taoists, because they discussed Buddhism in a Taoist vocabulary and sought in Buddhism solutions to Neo-Taoist problems such as the relation of the Holy

35 Hurvitz/Link 1974: 419, 444 (n. 94), 450, 465. (For the date of this collection, see n. 30 above.) Hurvitz and Link cite modern studies up to 1969, but still refer to the first edition of Liebenthal's Book of Chao rather than the second edition, which had probably not reached them yet.

36 Mather 1963: 348 (n. 83).

37 Robinson 1967: 3, 16, 105, 118, 159 respectively. Awkwardly, the index - which was not compiled by Robinson himself (see his "Acknowledgements", vii) - has an entry for "BuddhoTaoism" (330) despite the fact that Liebenthal's substantive form appears nowhere in the book. 
Man [shêng-jên 聖人] to the world, whether he really acts, and whether he feels compassion. The last luminary in this movement was Kumārajīva's young disciple Seng-chao. ${ }^{38}$

Thus was it Robinson who, for the first time, explicitly delineated the semantic coverage of Liebenthal's neologism, sociologically, chronologically and intellectually: "Buddho-Taoists" were (a) Chinese Buddhist monks (b) who lived from the mid-fourth to early fifth century and (c) were well acquainted with the "Taoism" of their time. But did this definition also imply the conceptualisation of something - a creed, a thought, a trend - to be called "Buddho-Taoism"? Robinson, again, never used that substantive form in any of his books, and his untimely demise in the summer of 1970 brought the study of early Chinese Buddhists as "Buddho-Taoists" to a standstill. ${ }^{39}$

Robinson's definition retained some currency for a decade or two. For example, Harold Roth still included Chih Tun in a group of "Buddho-Taoists" in his 1974 M.A. dissertation. ${ }^{40}$ Jonathan Lipman too was still faithful to this definition when he mentioned "Buddho-Daoist geyi [格義] borrowing” in a 1984 paper primarily concerned with politics and ethnicity in north-western China in the first half of the twentieth century. ${ }^{41}$ The following year, Hurvitz may have been the last scholar of that generation to do so in his translation of the first volume of Tsukamoto Zenryū's 塚本善隆 (1898-1980) history of Chinese Buddhism, ${ }^{42}$ focused on the Northern Wei 北魏 dynasty (386-534). Perhaps giving in to a growing trend (see the next sections), Hurvitz used Liebenthal's substantive form, albeit once and in an interpolated section title ("From Taoistic Buddhism to Buddho-Taoism") with no equivalent in the Japanese original. ${ }^{43}$

38 Robinson 1970: 80-81. Further on, Robinson added: “The Buddho-Taoists, amalgamating the general Indian doctrine that the Buddha adapts his teaching to his hearers' capacity and the Taoist ideal of going with the grain of the Tao, had said repeatedly that the Holy Man accords with things, teaches according to the critical situation, responds to appeals" (92).

39 On Robinson's accidental death, see the obituary by Link and Hurvitz (1971).

40 Roth 1974: iii.

41 Lipman 1984: 297.

42 Tsukamoto 1979 [1968].

43 Tsukamoto 1985: 121. In order to adapt into English the style of the Japanese Buddhist monk, Hurvitz resorted to a varied phraseology in part going back to Maspero. He translated "dōkyō-teki Bukkyō" 道教的佛教 and “han-dōkyō-teki Bukkyō" 反道教的佛教 (1979 [1968]: 126) as “Taoistic Buddhism” and “anti-Taoist Buddhism” (1985: 122), whilst "a Buddho-Taoist hodgepodge” (1985: 133) rendered “Butsu-dō shūgō no shūkyō” 佛道習合の宗教 (1979 [1968]: 135). Buddhism was first regarded in China as "a sort of Indian Taoism”, hence “Taoistically received” (1985: 186; “iwaba Indo no dōkyō” いわばインドの道教 and “dōkyō-teki ni juyōsareta” 道教的に受容された, 1979 [1968]: 190), etc. 
Meanwhile, Robinson's second book, with no less than four re-editions between the late nineteen-seventies and 2005, must have proved a commercial success. If both "Buddho-Taoist" passages quoted above remained unchanged in the second edition (1977), the third edition (1982), however, retained solely the first passage, the section containing the second one being reorganised and partly rewritten. ${ }^{44}$ The fourth edition (1997) introduced Liebenthal's substantive form as "[the application of] Buddhist ideas to issues that had been raised in Confucian and Taoist intellectual circles during the third century" and featured a new section boldly titled "The Era of Buddho-Taoism", which surveyed thirdand fourth-century intellectual life in China, the Learning of the Dark (rendered as "Arcane Learning"), "neo-Taoism", Tao-an and Hui-yüan. ${ }^{45}$ That new section was re-titled simply "Buddho-Taoism" in the latest edition to date. ${ }^{46}$

\section{Temporal and semantic dislocations, and Zürcher's influence}

But even before Robinson's efforts at circumscribing its coverage, Liebenthal's neologism soon served a variety of purposes in disregard of both the historical and cultural processes to which it had been applied originally. The American Arthur F. Wright (1913-1976), though he belonged to a younger generation, published on Chinese Buddhism around the same time as Liebenthal did. Wright was clearly adapting Maspero's "taoïsme bouddhisant" when he mentioned the "early Taoistic-Buddhist community" of Loyang. ${ }^{47}$ Concerning Liebenthal's substantive, though I did not find a single occurrence of it in Wright's work, it is worth noting that he did use the adjectival form in his book on Buddhism in Chinese History (1959), where he evoked "a BuddhoTaoist religion of many gods and many cults", fustigating the "corrupt and illiterate Buddho-Taoist clergy" and wondering how long would the Chinese agrarian people "cling to its Buddho-Taoist folk religion" ${ }^{48}$ The novelty was that, in all three cases, Wright was not writing about Buddhism in the early medieval era, but about Chinese religions in modern times. In effect, Wright

44 Robinson 1977: 147, 162; 1982: 162.

45 Robinson/Johnson 1997: 178-181.

46 Robinson/Johnson/DeGraff 2005: 180-183. This edition now has a title in the plural ("Buddhist religions") and renders hsüan-hsüeh as "Speculative metaphysics" (181).

47 Wright 1957: 23, with a reference to Maspero 1934 in n. 12.

48 Wright 1959: 111, 115, 122. 
stretched the upper chronological limit of Liebenthal's neologism up to the twentieth century.

Only three years later, in the introduction to his English translation of the Records of a Journey to the West (Hsi-yu lu 西遊錄), an anti-Taoist pamphlet composed by Yeh-lü Ch'u-ts’ai 耶律楚材 (1189-1243), the Italian historian and philologist Igor de Rachewiltz mentioned the "Buddho-Taoist controversy in the middle of the [thirteenth] century, culminating with the great proscription of Taoist apocryphal literature in 1281 ". ${ }^{49}$ This latter case may be compared to a paper by Hok-Lam Chan 陳學霖 also dealing with the Yüan 元 dynasty (12711368). Chan singled out as “a Buddhist-Taoist” Liu Ping-chung 劉秉忠 (12161274), a Ch'an 禪 Buddhist “who emerged from his seclusion to become Khubilai's chief counselor and a leading figure among the Chinese literati", but who really was, in Chan's view, a "half-hearted Buddhist adept and Taoist mystic". ${ }^{50}$ As a hypothesis for this choice of "Buddhist-Taoist", a form earlier than Liebenthal's coinage as we have seen, Chan may have felt some reticence to apply to the thirteenth century a neologism primarily intended to describe Buddhism in early medieval China.

In his somewhat late review of a Chinese book published in Hong Kong in 1962, David C. Yu 俞檢身 called "Buddho-Taoist” the chên-k’ung chiao 真 空教 ("Religion of Perfect-emptiness" in his translation), an "apocalyptic" sect founded in 1862 by a former merchant and former Ch'an Buddhist monk who claimed to have received revelations encompassing no less than five known religions - "Confucianism, Taoism, Buddhism, Christianity, and Islam" - and whose writings displayed "certain religious symbols which are Buddho-Taoistic and anti-elitist". ${ }^{51}$ Regardless of the anecdotal use of an adjectival variant, $\mathrm{Yu}$ too seemed to outstretch both the chronological and confessional focus of Liebenthal's neologism. In a paper nearly contemporaneous, however, Yu acknowledged "Buddho-Taoism" as denoting the product of "the happy marriage between the Prajñā school and Neo-Taoism", a statement more in line with Liebenthal and Robinson, suggesting that his "Buddho-Taoistic" may have reflected a conscious avoidance strategy on his part. $^{52}$

49 de Rachewiltz 1962: 2.

50 Chan 1967: 100, 145. In Chinese historiography, Khubilai or Kublai Khan (1215-1294) bears the imperial temple title (miao-hao 廟號) Shih-tsu 世祖 (r. 1260-1294).

$51 \mathrm{Yu}$ 1971: 157, 159. The fact that I did not encounter the variant "Buddho-Taoistic" elsewhere does not prove that it was never used again, but suggests that it never took hold in academic discourse.

52 Yu 1974: 419. 
Liebenthal, by then an honorary professor at the University of Tübingen, Germany, almost retired from publishing, and Robinson's élan broken off, the neologism began to fall into disuse in nineteen-seventies Buddhologist publications, whilst increasingly functioning elsewhere as a mere synonym for "early Chinese Buddhism”. For example, Roger Corless (1938-2007), in a short contribution to a 1975 collective work, introduced a geographical nuance when he explained that "Buddho-Taoism expressed Buddhist ideas in Taoist terminology. In the north, its ability to perform magic impressed barbarian rulers, while in the south, its philosophical profundities attracted the Chinese intelligentsia". ${ }^{53}$ At this point, the cultural and historical extent of Liebenthal's neologism could hardly have been more blurred.

Erik Zürcher, to my knowledge, resorted only belatedly to Liebenthal's substantive form in his published work. ${ }^{54} \mathrm{He}$ did, however, often use the adjectival form, as early as 1959 , in a chapter of his published doctoral dissertation, The Buddhist Conquest of China, which was to have a lasting influence on the evolution of the comparative field of Buddhist and Taoist studies. In that chapter, titled "The Conversion of the Barbarians: The Early History of a Buddho-Taoist Conflict”, Zürcher documented, in far greater detail than the few scholars who had done so before him, the Taoist contention that Lao-tzŭ converted Central and Southern Asians to a lower form of Taoism, and how Chinese Buddhists reacted to it. ${ }^{55}$ The impact of Zürcher's book was acknowledged in many subsequent publications, including by Link and, in the preface to the second edition of his Book of Chao, by Liebenthal himself. ${ }^{56}$

As far as the neologism is concerned, by keeping to the adjective, Zürcher was formally restricting it to the same primary dual meaning conveyed by Kenneth Ch'en's earlier adjective form. Despite his neglect of Liebenthal's substantive forms ("Buddho-Taoism" and "Buddho-Taoists"), Zücher's publications from the turn of the nineteen-eighties onwards proved instrumental in spreading the idea that not only did advocates of the Buddhist and Taoist faiths interact on the terminological and doctrinal levels, as other scholars had shown, but furthermore, that these processes created some new, mixed cultural entity. For instance, after searching two dozen early texts of the Numinous Treasure or

53 Corless 1975: 190.

54 In his "Preface” to Martin Rhie 2007: xv, Zürcher called "early Buddho-Taoism” the "association" of Buddha with "the Taoist deity Xiwang mu [西王母]” in late Han Buddhist iconography.

55 Zürcher 1959: ch. 6.

56 Link 1961: 136 ("a Buddho-Taoist controversy which was to have enormous consequences for both Buddhists and Taoists”; Zürcher's book chapter is referred to in n. 1); Liebenthal 1968: xi. For an assessment of the impact of Zürcher's book and its limits, see Silk 2008. 
Sacred Jewel (ling-pao 靈寶) Taoist sect, he concluded that "particularly in that tradition we find a number of scriptures in which borrowed terminological, stylistic and conceptual elements reach such proportions that we can almost speak of 'Buddho-Taoist hybrids'," which in turn led him to the hypothesis later to be elaborated upon, as we shall see - that Numinous Treasure may have "owed its very existence to Buddho-Taoist crossbreeding". ${ }^{57}$ Further analysing this case of "hybridization", he called some sutras composed in China "BuddhoTaoist hybrids" in which "Buddhist and indigenous (notably Taoist) elements were freely combined and amalgamated", a statement that still retained traces of how earlier Buddhologists used Liebenthal's coinage. ${ }^{58}$ Wishing to trace "the emergence of a Buddho-Taoist complex of eschatological beliefs and expectations", he focused on a specimen of what he called a "Buddho-Taoist merger", the Sutra of the Monk Shou-lo (Shou-lo pi-ch'iu ching 首羅比丘經), known thanks to a cluster of Tunhuang manuscripts. ${ }^{59}$ In a 1993 conference paper first published in 1999, he deplored that, "about the lowest stratum of diffusion - the level at which Buddhist elements were incorporated into Chinese popular religion - very little information can be found in written sources, apart from stray references to a hybrid Buddho-Taoist cult in later Han court circles". ${ }^{60}$ In sum, Zürcher's writings gave a new conceptual turn to the development of the adjective "Buddho-Taoist", which came to denote less the conditions of interplay of two separate entities than the singularised product of the process.

\section{5 "Buddho-Taoism" in the field of Taoist studies: Strickmann's and Seidel's influence}

At this point, moving back a few years will help us better appreciate Zürcher's influence on the evolutions of Liebenthal's coinage. In September 1968 in Bellagio, Italy, was held the first Conference on Taoist Studies. The participants

57 Zürcher 1980: 85, 144. Also in this paper (1980: 120), Zürcher deemed the term "Neo-Taoism" inappropriate to describe the trend known as "Learning of the Dark", hsüan-hsüeh (see n. 26 above).

58 Zürcher 1981: 35-36. Buddhism in the Han 漢 era (206 BCE-220 CE) is called again a case of “extreme hybridization” in Zürcher 1990: 182.

59 Zürcher 1982b: 2, 47.

60 Zürcher 1999: 18. (Together with the whole conference volume, that paper was recently republished under the same title in McRae/Nattier 2012: 1-25.) Zürcher was alluding here to sacrifices made by Emperor Huan 桓帝 (r. 146-168) to Lao-tzŭ and the Buddha at the same time, as reported by the official historiography of the period. 
included the above-mentioned Link, Mather and Wright, and a promising young German-born Sinologist, Anna Seidel (1938-1991). ${ }^{61}$ Holmes Welch (1924-1981) compiled the conference report that was published in late 1969. Welch's report bears no mention of Zürcher, not because Buddhist experts were deemed out of place (as the participation of Link shows) but rather, perhaps, because during most of the nineteen-sixties and -seventies, Zürcher did not publish much in the wake of his ground-breaking book. ${ }^{62}$ According to Welch, one of the themes that the participants discussed was "the Taoist-Buddhist interaction". His own list of "substantive problems for future Taoist research" included "the interaction between Taoism and Buddhism, especially Tantric Buddhism”, and some participants, elaborating upon the topic of "the relationship of Taoism with Buddhism", formulated further questions covering, among other topics, how some Buddhist and Taoist features did "interact" or "compare", and "what role did Taoism play in the sinification of Buddhism". 63 Though neither Liebenthal's neologism in any form nor Zürcher's name appear in Welch's report, the Buddhist Conquest of China is cited in the conference papers by Link and Seidel featured in the same journal issue, and Link's paper - faithful to Liebenthal and Robinson - also mentions the "Buddho-Taoists" and "BuddhoTaoist authors" of Tao-an's period. ${ }^{64}$

As a hypothesis, at this point, Sinologists working on Taoism may have felt unconcerned with the Buddhologist neologism or still reluctant to endorse it, possibly preferring the earlier dual form imagined by Ch'en. (It is impossible to ascertain whether Welch used "Taoist-Buddhist" because he heard it during the conference or on his own initiative. In the latter case, he may have been familiar with Ch'en's writings and have chosen deliberately “Taoist-Buddhist” over Liebenthal's coinage.) Moreover, Zürcher's recognition in the field of Taoist studies must then have been limited to the very few scholars who paid some attention to how things Buddhist evolved in Chinese context. It took a decade for this situation to change, as seen notably in the writings of Michel Strickmann (1942-1994), an American Sinologist mainly known for his work on Taoism. In a

61 By then, Seidel was preparing her recently defended doctoral dissertation for publication under the title La Divinisation de Lao tseu dans le taoisme des Han (1969). In this book, she referred to Zürcher's Buddhist Conquest of China - 39 (n. 2), 49 (n. 1), 90 (n. 4), 106 - and included a short "Note on the Issue of Buddhist Influences" ("Note sur la question des influences bouddhiques", 105-110), but she did not use either form of the neologism. In addition to Zürcher, her bibliography referenced Ch'en, but not Liebenthal.

62 For Zürcher's activity during those decades, see Silk 2013: 7.

63 Welch 1969/1970: 112, 133-134, 136.

64 Seidel 1969/1970: 224 (n. 23); Link 1969/1970: 182 (n. 2), 184, 190 (n. 21), 191 (nn. 25-26, 28), 196, 201 (n. 48), 202, 210 (n. 62), 214. 
paper dealing mostly with fifth-century China, Strickmann voiced the need "to determine the full extent of Buddho-Taoist textual and ritual interchangeability”. ${ }^{65}$ Elsewhere, he evoked Mount Mao (Mao Shan 茅山, in today’s Kansu Province) as "the most highly advanced centre of Buddho-Taoist synthesis" in sixth-century China. ${ }^{66}$ At the Quatrième Colloque Pluridisciplinaire FrancoJaponais held in 1985 in Paris, Strickmann gave a talk on "a Buddho-Taoist technique of exorcism", published only belatedly. ${ }^{67}$ In another posthumous work, he wrote that, "by the fifth century, the basic amalgam of BuddhoTaoist ritual was already in process - an amalgam that has influenced Chinese culture down to our time". ${ }^{6}$

Strickmann's bold appropriation of Liebenthal's coinage and use in the field of Taoist studies seemed to concern the adjective form only. But a major paradigm shift would take place in 1984 when Seidel, who may have discovered the Buddhologist's substantive on the occasion of the Bellagio 1968 conference, proposed a transposed variant seemingly of her own making, "TaoBuddhism", providing both terms with a definition that acknowledged the intrinsically instable semantics of either form:

Grâce aux archives de Touen-houang, qui nous ont donné accès à des textes religieux exempts des remaniements qu'ont subi les canons, nous découvrons, à l'autre extrémité de la gamme, une religion du peuple (à ne pas confondre avec la religion populaire) qu'on pourrait appeler Bouddho-taoïsme ou "Tao-bouddhisme" selon la prépondérance de l'une ou l'autre religion dans un courant ou une source donnée. ${ }^{69}$

It is not entirely clear if Seidel had in mind, to put it simplistically, to restrict the earlier neologism to how early Chinese Buddhists "borrowed" from Taoism (as per Liebenthal and Robinson) and her own variant to how some Taoists in

65 Strickmann 1990: 95 (the adjective form returns on p. 101). On p. 106 (n. 1), Strickmann explains that "the text [of the published version] dates entirely from 1977" and only footnotes have been updated.

66 Strickmann 1978: 472 (n. 21).

67 The paper appeared nearly two decades later as a chapter in one of Strickmann's posthumous opera, Chinese Magical Medicine (2002: 123-193). In his review of the book, Henrik Sørensen (2004) also used Liebenthal's adjective form several times, without ever addressing the question of its meaning.

68 Strickmann 2005: 2. In both posthumous publications, I assume the wording to be Strickmann's own rather than the result of the editing of his drafts by Bernard Faure.

69 Seidel 1984: 307 (her capitalisation). The passage may translate as: "Thanks to the Tunhuang archives, which have given us access to religious texts free from the rearrangements undergone by the canons, we discover, at the other end of the range, a religion of the people (not to be confused with popular religion) that we might call Buddho-Taoism or 'Tao-Buddhism' according to the preponderance of one religion or the other in a given current or source". 
turn "borrowed" from Buddhism to the point of "cross-breeding", "hybridisation" or "synthesis" (as per Zürcher and Strickmann). ${ }^{70}$ However helpful her differentiation may have been, things turned out differently. Sanctioned by a talented and increasingly influential scholar, this idea that Buddho-Taoism was "a religion" (singular) proved successful and inspirational both within and outside of Taoist studies. By contrast, her variant "Tao-Buddhism" failed to become widespread and is encountered very rarely, sometimes under the corresponding adjectival form. ${ }^{71}$

\section{The vogue of "Buddho-Taoism" and its consequences}

It cannot be mere coincidence that, subsequently to its multivalent recuperation by Zürcher, Strickmann and Seidel, Liebenthal's neologism quickly became fashionable to the point that anyone in the broadest field of Chinese studies seemed compelled to use it at least once whenever writing about virtually anything that involved Buddhism and Taoism. The majority case concerns the adjectival form, many occurrences of which just reiterate previous scholarship: the phrases "Buddho-Taoist conflict" (or "polemics", "controversy", etc.) and "Buddho-Taoist synthesis" (or "hybridisation", "amalgam”, etc.) in particular

70 In the same work's penultimate section on "The Taoist Basis of Buddho-Taoism" (1984: 325-336, "La base taoïste du Buddho-Taoïsme"), Seidel seemed to discuss "Buddho-Taoism" as if meaning how the early medieval Chinese viewed Buddhism as being "the Taoist religion of the barbarians" (332, "la religion taoïste des barbares"), that is, perhaps as Zürcher would have defined the substantive form if he ever had. Her "Abréviations et bibliographie" (1984: 351-352) lists works by Zürcher and Strickmann.

71 See Bokenkamp 1996 for an isolated use of "Dao-Buddhism" (in the paper's title). Bokenkamp's conclusion was that what had been called hitherto "Buddho-Daoist piety" may simply be what is otherwise known as Numinous Treasure, ling-pao (1996: 67). Though certainly a tribute to Seidel, whose untimely death was still in everyone's mind (volume 9 of the Cahiers d'Extrême-Asie was one of several journal issues to be dedicated to her memory), the paper's title is misleading, because the analysis is exclusively philological - thus it is not the "stele" itself that Bokenkamp saw as "evidence for the 'Dao-Buddhism' of the early Lingbao scriptures", but rather the contents of the stele inscription. At any rate, Seidel's variant does not appear anywhere else in Bokenkamp's paper, nor does any earlier substantive form. Other isolated occurrences include "the 'Tao-Buddhist' messianic text studied by Anna Seidel" (Zürcher 1982b: 36, n. 68), “Tao-Buddhist conception” (Santangelo 2000: 467) and a "celebrated Dao-Buddhist patriarch" (Schmidt 2006: 301). As we shall see, Seidel's variant is among the terms criticised by Robert Campany. 
are abundantly attested, suggesting that they rapidly became clichés. ${ }^{72}$ Such reiterations have in common that they forgo any temporal or cultural delineation other than those sometimes contextually implied. This swift contamination of Sinological discourse was bound to aggravate the semantic dislocations that, as we have seen, threatened the neologism right from its inception. From the nineteen-eighties on, only rarely was it used in connection with the first generations of Chinese Buddhists, for instance when Isabelle Robinet (1932-2000) wrote of totally merging yu 有 (existence or being) and $w u$ 無 (non-existence or non-being) as being "the Buddho-Taoist project", on the same wavelength as Liebenthal and Robinson. ${ }^{73}$ By then, the adjective had become common in reference to a variety of religious phenomena, for instance when evoking "Buddho-Taoists beliefs, in which the Future Buddha, Maitreya, played the role of Taoist sage". ${ }^{74}$ Leaving behind the fourth and fifth centuries, it became increasingly applied to the T'ang dynasty and beyond, ${ }^{75}$ to the Sung 宋 (9601279) era, $^{76}$ and up to Ming-Ch'ing times (late fourteenth to early twentieth century), which were, according to Whalen Lai 黎惠倫, “another period of Buddho-Taoist synthesis". 77 Hubert Seiwert described as a "synthesis of

72 I keep here to a selection of secondary sources chronologically arranged: Bokenkamp 1990: 119 ("the Buddho-Taoist interplay"), 120 ("Buddho-Taoist controversies"), 122 ("Buddho-Taoist debates”); Lai 1990: 183 (“Buddho-Taoist syncretism”), 204 (n. 91: "Buddho-Taoist fusion”); Kohn 1990: 627 ("Buddho-Taoist controversy”), 628 (“Buddho-Taoist mixtures”); Kohn 1991: 149 (“Buddho-Taoist synthesis”); Verellen 1992: 233 (“Buddho-Taoist interaction”); Campany 1993: 1 ("Buddho-Taoist interaction”); Robson 1995: 223 ("Buddho-Daoist polemical debates”); Barrett 1996: 31 (n. 24: "Buddho-Taoist conflict”), 32 ("Buddho-Taoist polemics"); Penny 1996: 1 ("Buddhist-Daoist interaction"); Campany 2002: 431 (a Taoist text whose title is reminiscent of Buddhism is described as "a text with a heavily Buddho-Daoist title"); Bokenkamp 2004: 318 ("the 'Buddho-Taoist' syncretism of the Lingbao movement").

73 Robinet 1995: 218 (“le projet bouddho-taoïste”).

74 Barrett 1983: 336.

75 See Bien 1985: 133 (the "Buddho-Taoist detachment" of a ninth-century poet); Drège 1991: 134 (“controverse bouddho-taoïque”), 256 (“ouvrages bouddhiques ou bouddho-taoïques"). Following in the footsteps of Seidel, Verellen 2000: 274 states that, "after nearly a thousand years" of presence in China, Buddhism was still perceived as "a foreign doctrine", but had progressively become "impregnated" with Taoism and vice versa, to the point that "one may almost speak of a new Chinese religion of Buddho-Taoist inspiration" ("une nouvelle religion chinoise d'inspiration bouddho-taoïste").

76 Morgan 1996: 334 ("a system that linked salvation to the revivifying powers of a sacred script was transformed into a Buddho-Taoist method that stressed the supremacy of the spoken word").

77 Lai 1987: 30. The phrase "Buddho-Taoist synthesis" appears three times in the paper (11, 19, 30). Robinet 1994: 44 describes the thought of the Neo-Confucian Wang Chi 王畿 (1498-1583), a disciple of Wang Yang-ming 王陽明 (1472-1529), as being heavily influenced by “a Buddho- 
Daoist, Buddhist, and popular tradition [presaging] the main characteristic of later sects" what he called "new Buddho-Daoist millenarianism" in fifth-century China. ${ }^{78}$ Around the turn of the millennium, the neologism was even propagated into the broader East Asian field, beyond the boundaries of the polity we call "China" today. ${ }^{79}$

It was therefore inevitable that, serving such a variety of purposes, the neologism would soon lose any defining criterion, degrade into a hollow shell and ultimately go out of fashion. For example, Charles Holcombe's book In the Shadow of the Han (1994), not primarily concerned with religion, features six occurrences of the adjectival form, all functioning as shorthand substitute for the plainer phrase "Buddhist and Taoist". ${ }^{80}$ Also strikingly relevant in this regard is the collective bibliography on "Chinese Religions: The State of the Field" compiled for the 1995 issue of The Journal of Asian Studies, which includes a whole section on "Buddho-Taoism" that affirms the topic to be "essential but neglected", and yet never defines it. ${ }^{81}$ Instead, the reader is referred to Seidel's classic "Chronicle of Taoist Studies in the West”, a section of which bears the title "Taoism and Buddhism" - not "Buddho-Taoism" - and, keeping to the adjective form (ten occurrences or so), traces the early developments of the modern comparative study of both religions. ${ }^{82}$

David Mungello's The Great Encounter of China and the West (1999) presents us with a case comparable to Holcombe's In the Shadow of the

Taoist 'subitist' and holistic tendency" ("une tendance 'subitiste' et globalisante bouddhotaoïste”).

78 Seiwert 2003: 90-91. Though acknowledging that "there is no information about the social milieu where this kind of popular Buddho-Daoist millenarianism was propagated", Seiwert nevertheless suspects that "it was far more widespread than the scarce sources suggest".

79 Miller 2000: 87 ("the 'sudden awakening' motif" found in many East Asian folktales is a "Buddho-Taoist idea [holding] that the ordinary world of perception is not in fact real in the ultimate sense").

80 Holcombe 1994: 83 ("Buddho-Taoist metaphysical wisdom”), 87 ("Buddho-Taoist reclusiveness"), 111 ("the Buddho-Taoist concept of ultimate void”), 126 ("Buddho-Taoist equanimity" and "a Buddho-Taoist model of detachment"), 134 ("Buddho-Taoist philosophical and religious innovations"). Though the substantive form never appears in the book, the author, in a contemporaneous paper, referred the reader to it for a treatment of "Buddho-Taoism in the fourth century" (Holcombe 1995: 9, n. 72). That paper also evokes "Buddho-Taoist philosophy" (9) and "the 'pseudobureaucratic' order of Buddho-Taoist southern-dynasty society" (13), without elucidation.

81 Verellen 1995: 328.

82 Seidel 1989/1990: 287-296 ("VII. Taoism and Buddhism”). Seidel also used her own variant once, evoking "the vast Ming dynasty Buddho-Taoist (or Tao-Buddhist, depending on the temple's tradition) pantheon” (272). 
Han. The book's first and second editions ignored the neologism, treating instead Buddhism and Taoism as discrete lexical, syntactical and presumably semantical entities. ${ }^{83}$ Then, somehow, the neologism worked its way into the third and fourth editions. A passage in the third edition reads: "Instead of blending Buddhism and Daoism with Confucianism, the Jesuits thought to blend Christianity with Confucianism. They did this by attempting to displace Buddho-Daoism with Christianity and to create a Confucian-Christian synthesis". ${ }^{4}$ In both earlier editions, the same passage read "Buddhism and Daoism" instead of "Buddho-Daoism". One is left to wonder about the necessity of the rewording and its conceptual or heuristic implications, if any, considering that the general context remained untouched. In addition, the same edition had a new section on "Female infanticide" mentioning "Buddho-Daoist popular religion" and "Buddho-Daoist folk religion", and even included an illustration with a caption evoking, extraordinarily, a "Buddho-Daoist priest [...] holding a rosary". 85

Even though, as we shall see further on, the neologism began to be criticised already during the nineteen-eighties, its latest confident uses coincide with the first decade of the present century. One of the most noteworthy cases appears in Stephen Teiser's inspired "Foreword to the third edition" (2007) of Zürcher's nowadays classic Buddhist Conquest of China. Wishing to compare Zürcher's book to T'ang Yung-t'ung's 湯用粀 (1893-1964) History of Buddhism in the Han, Wei, two Chin, and Southern and Northern Dynasties (1938), an earlier work in Chinese also on the formative phase of Chinese Buddhism during the early medieval era, Teiser translated all chapter titles from that work, the fifth being rendered as "Buddho-Daoism". ${ }^{86}$ The purpose of T'ang's chapter, however, was to evaluate the peculiarity of some Buddhist features in the context of various "ways" (tao) during the Latter Han dynasty and beyond, and its original title was "Fo-tao" 佛道, for which "the way of Buddha" is the most straightforward, least interpretative rendition. ${ }^{87}$ In late Han times, tao retained the classical sense of a moral path or a secret expertise, a set of techniques or practices, or a religious tradition or faith, and its

83 Mungello 1999, 2005.

84 Mungello 2009: 23.

85 Mungello 2009: 48, 134-139. Except for the illustration's caption, all those occurrences appear again in the fourth edition (2013: 21-22, 145, 147).

86 Zürcher 2007: xviii. The spelling "Daoism" consistently replaces "Taoism" in this digitised edition, but the overall book layout and page numbering remain unchanged. The original title of T'ang's book is Han Wei liang-Chin nan-pei-ch'ao Fo-chiao-shih 漢魏兩晉南北朝佛教史 and its latest edition seems to be that published by the Peking University Press in 2011.

87 T’ang 1938: ch. 5. 
usage was in no way confined to a single individual or human group. ${ }^{88}$ And, naturally, as of writing this book, T'ang could hardly have had in mind to translate into Chinese a new Western term that would not appear in print before another full decade elapsed.

\section{7 "Buddho-Taoism" in iconography and epigraphy}

Considering how medieval Taoist and Buddhist faithful shared votive space, media and funerary costs, Chinese epigraphy and iconography are perhaps the fields where the heuristic validity of Liebenthal's coinage would best be put to test. Seidel again, though not primarily trained in those fields, opened Pandora's Box when, relying on Chinese accounts of artefact findings and their Japanese interpretation, she contended that a cluster of fifth- and sixth-century epigraphic sources "show not only that there existed communities worshipping both Buddha and the highest Taoist deity, they also allow a glimpse at a milieu where Taoism and Buddhism seem not to have been distinguished clearly" ${ }^{89}$ Also extrapolating from Chinese excavation reports, the art historian Jean M. James preferred to use the form "Taoist-Buddhist" in the title of her contemporaneous study of the "intermingling and conflation" of Buddhist and Taoist images from the fifth century onwards. Not unlike Seidel, James saw in her materials "indigenous images [that express] quite clearly the combination or merging of the early Buddhist and Daoist religions in the popular mind during the formative years of Daoism", but she nevertheless insisted that Taoist images were "recognized by the Daoist faithful as representing a Daoist deity" whilst "Buddhist images [were] made for devout Buddhists who never, in any way, confused their gods with those of the Daoists". ${ }^{90}$ Also around the same time, in a study of "Buddhist elements in early Chinese art" focused on an even earlier site in northern Kiangsu Province, Wu Hung held that the carvings found there, hitherto regarded as "the earliest Buddhist art in China", should be considered more appropriately "the earliest examples of Taoist art" due to the Taoist nature

88 This was already made clear forty years ago by Fukui Fumimasa 福井文雅 (1977) and Arthur Link (in Tsukamoto 1985: 1007-1008).

89 "Ces quelques inscriptions montrent non seulement qu'il y existait des communautés qui rendaient un culte à la fois au Buddha et à la plus haute divinité taoïste, mais elles laissent entrevoir un milieu où Taoïsme et Bouddhisme ne semblent pas avoir été nettement distingués" (Seidel 1984: 336). The capitalisation is Seidel's.

90 James 1989: 71, 73. 
of the site and can certainly not be interpreted as "a fusion of Buddhism and Taoism". 91

All three approaches allow a glimpse at the state of the field prior to the soaring popularity of Liebenthal's coinage in Chinese studies at large and its introduction, perhaps by Henrik H. Sørensen, into the field of Chinese iconography during the nineteen-nineties. In a 1995 paper, Sørensen first mentioned in passing "Song dynasty sculptural sites for Buddho-Daoist and Confucian worship", before pointing to a particular sculptural group from a Szechwan Province site as representing "Buddho-Confucianism (-Daoism)" due to the presence of "Vairocana/Rocana Buddha together with a semi-mythical Confucian sage (or highly ranked Daoist god, should the image in question turn out to be the Lord of Mount Tai)". ${ }^{92}$ In a slightly later paper, Sørensen praised a sculptural ensemble from a T'ang site for being "significant for its dual religious function and [providing] one of the earliest known examples of Buddho-Daoist sculptures" in Szechwan. ${ }^{93}$ Indeed both sites are known to have some images identified as Buddhist, some as Taoist, as well as votive materials related to either of the two faiths, but no visual or textual evidence allows one to speculate that both sets of features relate to a single religion of combinative nature. And if a given site is religiously "dual", then should the phrase "Taoist and Buddhist" not suffice to characterise it, without resorting to a dubious term lacking a clear, unique definition and already loaded with such a mixed subtext?

But the influence of the neologism on epigraphists and iconographers remained limited. In a paper published in the same tribute to Seidel as Stephen Bokenkamp's philological study of the so-called Yao Po-to 姚伯多 stele inscription dated to 496, the art historian Stanley Abe resorted to the peculiar form "Buddhist/Daoist" three times. ${ }^{94}$ Next to the phrases "Buddhist/

$91 \mathrm{Wu}$ 1986: 300, 303.

92 Sørensen 1995: 284, 300. The Lord of Mount Tai (T’ai-shan chün 泰山君) is also known as the Grand Emperor of the Eastern Peak (Tung-yüeh ta-ti 東获大帝). Parenthetically, the coinage "Buddho-Confucianism” appeared much earlier than Sørensen's paper: in 1962, Albert Dien had a paper published with the subtitle "A Buddho-Confucian". That particular combination, which goes beyond the scope of this paper, does not seem to have met with considerable success; for a comparable occurrence, dated 1988, see n. 94 below.

93 Sørensen 1998b: 43.

94 The earliest occurrences I could find of that peculiar form are in Teiser 1988: 40 ("Buddhist/ Taoist temples" and "Buddhist/Taoist priests"). Presumably Teiser's substitution of the hyphen in Kenneth Ch'en's "Buddhist-Taoist” for a slash indicates an alternative (Buddhist or Taoist temples, Buddhist or Taoist priests) rather than a compound meaning (something both Buddhist and Taoist), which an adjectival occurrence of the coinage in the same work (1988: 12, "Buddho- 
Daoist stele" and "Buddhist/Daoist image" - the latter being how Abe rendered the Chinese phrase Fo-tao hsiang 佛道像 from another fifth-century stele inscription - Abe also mentioned "the Daoist-Buddhist issue", preferring in that instance the same form as J. M. James. ${ }^{95}$ In his later book, Ordinary Images (2002), Abe again ignored Liebenthal's coinage, especially in a chapter devoted to fifth- to early sixth-century "Daoist and Buddhist-Daoist" artwork from Shensi Province. Therein, Abe now thought that local sculpture "reflects a rather more complex range of imagery and beliefs that defy any easy categorization" and challenged the characterisation of unusual visual features as reflecting "the errors, misunderstandings, or ignorance of provincial artisans [...] unacceptable to knowledgeable metropolitan elites"; rather, he suggested, "some works consciously deviated from normative models, while others were simply poorly executed or inexplicably finished". Abe even abandoned his earlier interpretation of a particular stele as being "a conscious hybrid donation by a BuddhistDaoist association" and, relying on the contents of the inscription, regarded the said association as having been "completely Daoist”. Nevertheless, when moving on to religious artwork from another Szechwan site, Abe still stressed the "variety of visual styles, levels of patronage, and religious motives - Buddhist and Daoist, as well as mixtures of the two - among these works", describing them as being "more or less Daoist [three examples], a conscious mixture of Daoist and Buddhist figures [two examples], or Buddhist with some anomalous mudras [one example]". But, when concluding, Abe confessed being "hesitant to consider any mixture of Buddhist and Daoist imagery as Lingbao inspired", thereby voicing disagreement with Bokenkamp's philological interpretation. ${ }^{96}$

Dorothy Wong also seemed reluctant to resort to Liebenthal's coinage when scrutinising materials similar to those that Abe discussed. She devoted a chapter of her own monograph on Chinese Steles (2004) to the mainly sixth-century "Buddhist-Daoist elements" in three "Buddhist-Daoist steles" recovered from sites also located in Shensi. She noted "the large number of Daoist and Buddhist-Daoist steles" coexisting with Buddhist ones on a given site, suggesting "a strong undercurrent of Daoism, which engaged in a vigorous dialogue with Buddhism”. Wong rendered Fo-tao in the names that modern Chinese scholars give to two steles as "Buddhist-Daoist", but then as "Buddhist and Daoist" when translating the phrase Fo-tao hsiang ("Buddhist and Daoist

Taoist pantheon") seems to confirm. Teiser also uses the phrase "a Buddho-Confucian” once (1988: 218).

95 Abe 1996: 71, 74-76. For Bokenkamp's study of the inscription from the same stele, see n. 71 above.

96 Abe 2002: 259, 272-274, 279, 281, 295. 
images") from an original inscription (to compare with Abe's rendition of the same phrase quoted above). But in her depiction of supposedly Taoist features observed together with typically Buddhist ones, Wong blended a limited number of specifically Taoist features with several "Han" - and, more generally speaking, "indigenous", that is, "Chinese" - motifs. ${ }^{97}$

In her recent study of eighth-century cliff sculptures also from Szechwan sites, including some already discussed by Sørensen, Christine Mollier also used "Daoist/Buddhist" a dozen times, in alternation with "Buddho-Daoist" (seven times) and "Buddhist/Daoist" (three times). The context of these occurrences suggests that each formula conveys a particular nuance expressed by the order of the combined terms: the most frequent formula would refer to observations in predominantly Taoist sites; the other two formulae, in predominantly Buddhist sites - which, if I am correct, would be in line with Seidel's 1984 proposal. At one point, however, the formula "Buddhist/Daoist" encompasses all three sites surveyed by Mollier, including a Buddhist site also studied by Sørensen. ${ }^{98}$ It would then seem that the predominance of Taoism also has a broader historical and political determination, in this case the pro-Taoist reign of T'ang emperor Hsüan-tsung 玄宗 (r. 712-756).

In sum, Liebenthal's coinage seemed at first to provide Chinese iconography and epigraphy with an easy way to depict thematic associations and visual features deemed problematic, but it failed to improve our understanding of various religious artefacts such as statues, bas reliefs and steles from the Chinese medieval and later eras. ${ }^{99}$ Quite the contrary, in addition to causing original materials to be misinterpreted, it also provoked a widespread confusion between inscription contents and the labels arbitrarily assigned to epigraphic artefacts by modern Chinese scholars mainly for classification purposes. ${ }^{100}$ In

97 Wong 2004: 107-109, 112, 115.

98 Mollier 2010: 103-105, 123. I hereby thank the author for kindly providing me with a copy of her work.

99 For example when Tansen Sen notes that "the Big Dippers in the Xuanhua paintings were, following existing custom (whether Daoist, Buddhist, or Buddho-Daoist), drawn to imply a particular period in time" (1999: 42). Though this is the only occurrence of the neologism in the paper, later on Sen states that "the focus on the Big Dipper may have been an outcome of Tantric-Daoist syncretism" (1999: 48), another isolated instance that adds to the reader's perplexity: Are the adjectives "Buddho-Daoist" and "Tantric-Daoist" exchangeable? And, if not, why is the latter not included in the earlier bracketed enumeration as a fourth possibility? 100 This is especially evident in Zhang 2010, a book chapter that contains a number of occurrences of "Buddho-Taoist stele" as translation for the phrase Fo-tao hsiang-pei 佛道像碑 appearing in stereotyped artefact names imagined by contemporary Chinese scholars (see Zhang 2010: 446-456, “Table 1: Northern Dynasties Daoist stelae”). In most cases, however, those artefacts originally bear no "name" or "title" at all, but rather written registers variously 
epigraphic material no less than in other textual sources, it is clear that, in late Han and early medieval times, Fo-tao simply meant "the way, or path, of Buddha" and referred to what is known as Chinese Buddhism today. ${ }^{101}$

\section{8 "Buddho-Taoism" from doubts to critiques, then disfavour}

The earliest expressions of circumspection towards the use of Liebenthal's neologism date back to the mid-nineteen-eighties, around the same time as the description of historical and cultural processes as "hybridism" and "syncretism" to began to meet with criticism. ${ }^{102}$ "Does the label "Buddho-Taoist', by which many of Taosheng's contemporaries were known, apply without qualification to Tao-sheng? If so, what exactly does the label mean?” wondered Young-Ho Kim in his 1985 dissertation on Tao-sheng's Lotus Sutra commentary, acknowledging the term's disturbing lack of a fixed definition and varying usage in a note: "The term Buddho-Taoism has a wide range of applications, from the early stage of conflict and interaction between the two components to the process of cultural amalgamation and synthesis of the two systems". ${ }^{103} \mathrm{~A}$ few years later, in a paper on the "Buddho-Taoist metaphysics of experience" presented to the International Symposium on East-West Cultural Interflow, Macau, 1993, Kenneth K. Inada (1924-2011) argued that Buddhism and Taoism "have molded a large segment of the Asiatic mind by their incomparable metaphysical basis of experiential reality", but he added cautiously: "Since both systems focus on and function from similar experiential grounds, I have grouped them together in delineating a BuddhoTaoist metaphysics, although admittedly any scholar would be wary, and rightly so, of identifying them in the strictest sense". ${ }^{104}$

arranged, as can be seen in such collections of photographic reproductions as Pei-ch'ao Fo-tao tsao-hsiang-pei ching-hsüan 北朝佛道造像碑精選 (1996), which includes both visual materials and transcriptions of textual contents from a selection of nineteen steles with inscriptions dated from 424 to 562. Neither that collection's English title nor the English abstract uses "BuddhoTaoism" or any variant thereof.

101 See Liu 2003: 56.

102 Such early critiques as Gimello 1978 heralded what would become an academic trend.

103 Kim 1985: 6, 17 (n. 7). These remarks appear again verbatim in the published version of the thesis (Kim 1990: xviii-xix).

104 Inada 1994: 31. Inada reworked this paper into a book chapter. In that later version, he still used the neologism, but again warned scholars not to treat Buddhist and Taoist metaphysics as "identical in the strictest sense" (Inada 1997: 86). 
Sørensen, despite his own use of Lietenthal's coinage in the field of iconography, voiced some concern over not only the term's definition, more importantly its validity as tool for historical description. In a short section on "Buddho-Daoist syncretism" contributed to a 1998 UNESCO-sponsored volume on the Silk Road network, he wrote:

We still lack information on the historical and practical aspects of this Buddho-Daoist syncretism including questions as to whether it existed as a sectarian reality with proper institutions or was simply practiced by Buddhists and Daoists alike irrespective of faith, the extent of its literature both in Dunhuang and in the central provinces of China, when it arose and the extent of its influence, and so forth. ${ }^{105}$

Though comparably late, Sørensen's realisation was quite to the point. Indeed, a change in scholarly attitudes towards inter-religious dynamics in their historical depth took place around the turn of the millennium. In a 1998 conference paper published in 2002, Charles Orzech contented that "to label a religion 'syncretic' or 'hybrid' (even with a hyphen, as in the term BuddhoDaoist) implies that there are two sorts of religion: the purebred and the bastard". ${ }^{106}$ In the often-cited introduction to his own study and translation of the Pao-tsang lun (2002), Robert Sharf rejected the representation of Buddhism as "an autonomous religious system that originated in India and assimilated (or was assimilated by) a variety of regional traditions and cults as it traveled across Asia”. Like Orzech, he criticised the idea of localised "syncretism”, giving as examples "Taoist-Buddhist syncretism in China, BonBuddhist syncretism in Tibet, Shinto-Buddhist syncretism in Japan" and stressing the "absence" or "unrecoverable" nature of the supposed "distinct religious entities that predate the syncretic amalgam". ${ }^{107}$ In the wake of these critiques, Ng Zhiru, whose 2007 book features the adjective form more than a dozen times, felt compelled to state in a note that the term served “descriptive purposes" only, prudently adding, without further elaboration: "I am not implying a 'corrupt' mixture of 'pure' breeds of

105 Sørensen 1998a: 34.

106 Orzech 2002: 214.

107 Sharf 2002a: 15-16. Only the adjectival form of the neologism appears in the book, in half a dozen occurrences of the expression "Buddho-Taoist debate" - 2002a: 54-55, 58, 60, 198, 229, 298 (n. 70), 301 (n. 104) - and, once, to criticise the idea of syncretism (2002a: 76, "It would be a mistake, however, to characterize the result as a species of Buddho-Taoist syncretism, since the truth expressed is, according to the Buddhist version, a Buddhist truth"). Sharf had already criticised "syncretism" in a 1997 conference paper, published the same year as his book (Sharf 2002b). 
Buddhism and Daoism". ${ }^{108}$ All this must have led Robert Campany, only a few years ago, to reject as obsolete the metaphors that we use when dealing with

mutual activity that results in some new thing that does not fit comfortably in either of the "parent" traditions. This new thing is often described as a hybrid or by such name as "DaoBuddhism" or "Buddho-Daoism," the nomenclature perhaps reflecting uncertainty as to how best to categorize the phenomena or a tacit recognition that the regnant metaphors have been stretched to their breaking point. ${ }^{109}$

It is quite ironical that those very Sinologists who had contributed to the spreading and denaturation of Liebenthal's coinage would deliver the coup de grâce themselves. Mainly composed of papers presented to an international conference on "Buddhism, Daoism, and Chinese Religion" held at Princeton University, 8-10 October 2010, volume 20 of the Cahiers d'Extrême-Asie (2011) evidenced the growing uneasiness surrounding the neologism, to the point that a foreword co-signed by Teiser and Verellen managed, within only a few lines, to both define it and tactfully discard it. According to the co-authors, the conference topics had originally been "loosely [grouped] under the heading 'Buddho-Daoism,' referring to hybrid forms of religious thought and practice engendered in the meeting of the two religions. However, in preparing the 2010 conference, [the organisers] decided to avoid this term, which tends to raise more questions than it answers". ${ }^{110}$ Remarkably, in their ensuing introduction, the same co-authors equated Buddho-Taoism with the Japanese phrase "bukkyo to dōkyō 仏教と道教”, whose literal meaning is simply “Buddhism and Taoism”. Then, in a tribute to the earliest contributors to this "subfield", they named Maspero, Fu Ch'in-chia 傅勤家 (dates unknown), T’ang Yung-t’ung, Paul Demiéville (1894-1979), Tsukamoto, Ch'en and Zürcher, but ignored Liebenthal, Link, Hurvitz and Robinson, that is, the Buddhologists responsible in the first place for the invention and earliest use of the term. Instead, in their view, the "grandest monument to Buddho-Daoist studies" remained the work of Strickmann, ${ }^{111}$ despite the fact that, as we have seen, Strickmann had first used the term in the late nineteen-seventies, three decades after its inception.

$108 \mathrm{Ng}$ 2007: 90 (n. 38). A draft reviewer may have suggested this mostly rhetorical disclaimer.

109 Campany 2012: 101.

110 Teiser/Verellen 2010b: iii.

111 Teiser/Verellen 2010a: 6, 8. To this survey may be compared Hsieh 2012 (titled in English "Syncretism and Interaction: A Review of Scholarship on the Relationship between Medieval Buddhism and Daoism"), which mentions over 120 references in Chinese, Japanese, English and French, but, exactly like the Cahiers d'Extrême-Asie issue, disregards Liebenthal, Link, Hurvitz and Robinson. In his defence, nowhere does Hsieh use "Buddho-Taoism", preferring instead the 


\section{Epilogue: "Buddho-Taoism" today}

When Liebenthal imagined the phrases "Buddho-Taoist" and "Buddho-Taoism" to describe the Chinese Buddhist Sêng-chao and some of his contemporaries and their thought, he could not foresee the long-term consequences of his invention. Like any neologism, these terms seemed to have the unquestionable advantage of enabling scholars to discourse on a topic more conveniently than a longer phrase would. But they took on a life of their own and proved to have many drawbacks, most conspicuously the implicit simplification of a complex phenomenology, the creation of an ever-elusive semantic, cultural and historical ghost, and lasting distortions in the Western hermeneutics of religiosity in nonEuropean context. It cannot be mere chance that, as of writing, there was never a book-length monograph with "Buddho-Taoism" in its title or subtitle.

And yet, moribund as it may seem today, the neologism has not entirely disappeared from academic writings. Rare "conservative" uses may still be encountered, apparently unaffected by its dismissal for purposes other than disciplinary nomenclature. Sørensen, for example, when discussing "spells and pseudo-spells" in a recent paper, seems to have renounced his earlier caution. As if relapsing to the heydays of Buddho-Taoism and cultural hybridism, he states confidently:

[The] borrowing [by Buddhists from the Daoist spell-literature], which at times took on the shape of appropriation of both text passages and textual structures, resulted in a curious amalgamation of concepts and beliefs which more than anything else reflects a sort of religious cross-over even to the point of constituting hybrid religion. [...] While this aspect of Buddho-Daoism is to some extent present in the canonical Buddhist material, it comes to the fore in the Dunhuang manuscripts and as such may be seen as representing Buddhist cum Daoist practice on-the-ground. ${ }^{112}$

Such conservative occurrences coexist with even less frequent "revisionist" (or "purist") uses, more in line with Liebenthal's original meaning. Exemplifying the latter case are $\mathrm{Mu}$ Soeng's definition of Buddho-Taoism neither as an academic field nor cultural hybrid, but as the "collaboration" of "neo-Taoist philosophers and Chinese Mahayana Buddhist monks, both of the scholarly and ascetic persuasion", and his evaluation of Sêng-chao's writings as "the

Chinese phrases Fo-tao chiao-shê 佛道交涉 and Fo-tao-chiao chiao-shê 佛道教交涉, both of which he renders as "interaction between Buddhism and Taoism".

112 Sørensen 2013: 115. The paper contains several occurrences of the neologism. In the same journal issue, Frederike Assandri also seems to take the neologism to mean "Buddho-Daoist mixtures” (2013: 35), which partly harks back to Kenneth Ch'en's 1945 paper, prior to Liebenthal's coining. 
hallmarks of Buddho-Taoism" in subsequent centuries. ${ }^{113}$ One may as well quote John Thompson who, in his book also on Sêng-chao, writes: "By the fourth century Buddhist xuanxue [玄學] ('Buddho-Daoism') was a major intellectual movement and it had a lasting impact on Chinese Buddhism. Chinese thinkers used xuanxue concepts and terms such as wu and wuwei in interpreting Buddhist ideas and continued to rely on the basic Buddho-Daoist ontological scheme for centuries". ${ }^{114}$ Quite evidently, Mu's and Thompson's understanding of "Buddho-Taoism" is rooted in the writings of Liebenthal and Robinson, and in view of their bibliographical references, it seems probable that both are either unaware of its appropriation and subsequent transformation in the field of Taoist studies, or unwilling to acknowledge it.

Such minority cases notwithstanding, today "Buddho-Taoism" mainly functions as a label for a field within Chinese studies devoted to the comparative study of the multifarious ways in which both religions interacted within the context of Chinese culture from late Han and early medieval times onwards, as evidenced by scriptural, iconographic, epigraphic and architectural materials. By and large, this is what Mollier and Robson have in mind, when the former defines it as the study of "the interaction of Buddhism with the other major Chinese religion, Taoism" and of the "particularly fruitful" "encounter" of "these two great religions" during the medieval era ${ }^{115}$; and when the latter recognises the "recent movement within Sinology known as 'Buddho-Daoist studies'," with reference to both Seidel's "Chronicle of Taoist Studies in the West" and Verellen's "Taoism". 116 This is how Zürcher and Teiser already understood the term, when the former exalted the "very promising field of comparative BuddhoTaoist studies" in the early nineteen-eighties and the latter praised Seidel's "important essays" published "in the [field] of Buddho-Taoism", with a reference to her 1984 book chapter. ${ }^{117}$

As a final remark, one may wonder if Liebenthal's coinage is really indispensable to label this comparative field. Not only has "Buddho-Taoism" become a highly versatile speech unit, as this paper has amply shown, it is also insidious, as statements such as the following quotation from a 2010 doctoral

$113 \mathrm{Mu}$ 2004: 49, 56. But that author tends to equate "Buddho-Taoism" with Ch'an Buddhism and freely applies the neologism to later historical periods, something Liebenthal and Robinson never did.

114 Thompson 2008: 65-66.

115 Mollier 2008: ix, 1-2. The book uses both the substantive (3 times) and adjectival form (19 times) of the neologism, which has an entry in the index (232).

116 Robson 2009: 3, 14 (“Buddho-Daoist studies" again), 331 (n. 3). Verellen's review of Robson's book also has a passing allusion to "Buddho-Daoism" (2011: 206).

117 Zürcher 1982a: 173; Teiser 1994: 2. 
dissertation remind us: "Many scholars working [on syncretism and hybridity in China] have preferred to eliminate Buddhism and Daoism as categories of analysis altogether in favor of conglomerate terms such as 'Buddho-Daoism' or simply 'Chinese religion' designed to emphasize the integration of Chinese traditions in practice". 118 In our age of anti-essentialism and post-Geertzian cultural theory, Liebenthal's neologism functions here as a conceptual step back towards the old category of "Chinese religion", which partook of the eminently Western discourse on "World Religions" that developed around the turn of the twentieth century. ${ }^{119}$ Any statement in this vein risks being understood as implying that the most appropriate way to categorise the religiosity of the (non-European) Other is to resort to catchall singular phrases - besides "Chinese religion", one thinks of "Asian religion" or "African religion" - that have less to do with areas of self-perceived or self-experienced common culture than exotic clichés - the subtext here being "Chineseness". That the metalinguistic coinage "Buddho-Taoism" never had any corresponding signifier in the source language should long have signalled to Chinese-proficient scholars that epistemic violence was taking place under the cover of hermeneutic discovery or heuristic experimentation. A dangerous ambiguity will persist as long as academic discourse carelessly uses a term (a) whose semantic load is multivalent (b) as if it could refer at the same time to a discrete object supposedly evidenced by source materials, and to the ongoing academic study of that object. ${ }^{120}$ After all, the comparative study of the "two major Chinese religions" was already conducted by such influential East Asian scholars as T’ang Yungt'ung in China, and Yoshioka Yoshitoyo 吉岡義豐 (1916-1979) and Kamata Shigeo 鎌田茂雄 (1927-2001) in Japan, well before “Buddho-Taoism” first appeared and spread in European-language publications. ${ }^{121}$ In sum, having proved even less appropriate and more problematic than their widespread

118 Salguero 2010: 83.

119 Critiques of "World Religion" as a Western-centred, Protestant-inspired construct began roughly a generation ago (Fitzgerald 1990) and peaked with Masuzawa's monograph (2005). There does not seem to exist any fixed nomenclature for "World Religions". Only recent works such as the Norton Anthology of World Religions acknowledge Taoism as one of the world's "six most important major, living, international religions" (quoting Jack Miles' "Preface" to Robson 2015: xxvi-xxvii; his emphasis).

120 Keeping to two recent examples already cited, Mollier (2008), having introduced "the field now usually referred to as 'Buddho-Taoism”" (see n. 115 above), writes further on of "BuddhoTaoist traditions" (22, 211), "Buddho-Taoist peregrinations" (133) and "Buddho-Taoist sculpture" (202); Robson (2009) also endorses "Buddho-Daoist studies" as a field (see n. 116 above), but then mentions "the Buddho-Daoist concept of 'guarding the one' (shouyi 守一)" in a section devoted to a ninth-century text (180).

121 In addition to T’ang 1938, early examples include Yoshioka 1959 and Kamata 1968. 
component terms, both substantive forms "Buddho-Taoism" (for a too vague cultural entity) and "Buddho-Taoists" (for certain people) should better be discarded altogether; and when the interplay of non-reified agencies conjures up the adjective form "Buddho-Taoist", the earlier form "Buddhist-Taoist" or a clearer full phrase will perhaps be less prone to misunderstanding and overinterpretation.

Correction statement: Correction added after ahead-of-print publication on 20 September 2017: Footnotes 42, 43, 88 and 120 were corrected.

\section{Bibliography}

Abe, Stanley K. (1996): “Northern Wei Daoist Sculpture from Shaanxi Province”. Cahiers d'Extrême-Asie 9: 69-83.

Abe, Stanley K. (2002): Ordinary Images. Chicago/London: The University of Chicago Press. Assandri, Frederike (2013): "Examples of Buddho-Daoist Interaction: Concepts of the Afterlife in Early Medieval Epigraphic Sources". The Electronic Journal of East and Central Asian Religions 1: 1-38.

Barrett, T. H. (1983): “The Study of Chinese Eschatology”. Modern Asian Studies 17.2: 333-351. Barrett, T. H. (1996): Taoism under the T'ang: Religion \& Empire during the Golden Age of Chinese History. London: The Wellsweep Press.

Barrett, T. H. (2010): "Religious Change under Eastern Han and Its Successors: Some Current Perspectives and Problems". In: China's Early Empires: A Re-appraisal. Edited by Michael Nylan and Michael Loewe. (University of Cambridge Oriental Publications; 67). Cambridge: Cambridge University Press, 430-448.

Bien, Gloria (1985): “Baudelaire in China”. Comparative Literature Studies 22.1: 121-135.

Bokenkamp, Stephen R. (1990): "Stages of Transcendence: The Bhumi Concept in Taoist Scripture". In: Chinese Buddhist Apocrypha. Edited by Robert E. Buswell, Jr. (Bibliotheca Indo-Buddhica Series; 114). Honolulu: University of Hawaii Press, 119-147.

Bokenkamp, Stephen R. (1996): “The Yao Boduo Stele as Evidence for the 'Dao-Buddhism' of the Early Lingbao Scriptures". Cahiers d'Extrême-Asie 9: 55-67.

Bokenkamp, Stephen (2001): "Lu Xiujing, Buddhism, and the First Daoist Canon”. In: Culture and Power in the Reconstitution of the Chinese Realm, 200-600. Edited by Scott Pearce, Audrey Spiro and Patricia Ebrey. (Harvard East Asian Monographs; 200). Cambridge/ London, 181-199.

Bokenkamp, Stephen R. (2004): “The Silkworm and the Bodhi Tree: The Lingbao Attempt to Replace Buddhism in China and Our Attempt to Place Lingbao Taoism". In: Religion and Chinese Society, vol. 1: Ancient and Medieval China. Edited by John Lagerwey. Hong Kong: The Chinese University Press, 317-339.

Buswell, Robert E., Jr. (ed.) (2004): Encyclopedia of Buddhism. New York: Macmillan Reference USA. 
Campany, Robert F. (1993): "Buddhist Revelation and Taoist Translation in Early Medieval China”. Taoist Resources 4.1: 1-29.

Campany, Robert Ford (2002): To Live as Long as Heaven and Earth: A Translation and Study of Ge Hong's Traditions of Divine Transcendents. (Daoist Classics; 2). Berkeley/Los Angeles: University of California Press.

Campany, Robert Ford (2003): “On the Very Idea of Religions (In the Modern West and in Early Medieval China)”. History of Religions 42.4: 287-319.

Campany, Robert Ford (2012): "Religious Repertoires and Contestation: A Case Study Based on Buddhist Miracle Tales". History of Religions 52.2: 99-141.

Carr, Michael (1990): “Whence the Pronunciation of Taoism?" Dictionaries: Journal of the Dictionary Society of North America 12: 55-74.

Chan, Hok-Lam 陳學霖 (1967): “Liu Ping-Chung 劉秉忠 (1216-74): A Buddhist-Taoist Statesman at the Court of Khubilai Khan”. T'oung Pao, Second Series 53.1/3: 98-146.

Ch'en, Kenneth K. S. 陳觀勝 (1945): “Buddhist-Taoist Mixtures in the Pa-shih-i-hua T'u”. Harvard Journal of Asiatic Studies 9.1: 1-12.

Ch'en, Kenneth (1956): “The Economic Background of the Hui-Ch'ang Suppression of Buddhism". Harvard Journal of Asiatic Studies 19.1/2: 67-105.

Ch'en, Kenneth K. S. (1964): Buddhism in China: A Historical Survey. Princeton: Princeton University Press.

Copp, Paul (2012): “Chinese Religion in the Sui and Tang Dynasties”. In: The Wiley-Blackwell Companion to Chinese Religions. Edited by Randall L. Nadeau. (Wiley-Blackwell Companions to Religion). Chichester: Wiley-Blackwell, 75-98.

Corless, Roger J. (1975): “History of Buddhism in China”. In: Buddhism: A Modern Perspective. Edited by Charles S. Prebish. University Park: The Pennsylvania State University, 190-193.

Dien, Albert E. (1962): "Yen Chih-t’ui (531-591+): A Buddho-Confucian”. In: Confucian Personalities. Edited by Arthur F. Wright and Denis Twitchett. Stanford: Stanford University Press, 43-64.

Drège, Jean-Pierre (1991): Les bibliothèques en Chine au temps des manuscrits (jusqu'au $X^{e}$ siècle). (Publications de l'École Française d'Extrême-Orient; 161). Paris.

Espesset, Grégoire (2017): Review of The Norton Anthology of World Religions: Daoism, edited by J. Robson. Religious Studies Review 43.1: 33-37.

Fitzgerald, Timothy (1990): “Hinduism and the ‘World Religion' Fallacy”. Religion 20: 101-118. Fukui Fumimasa 福井文雅 (1977): “Dōshi to dōjin / Sono gogi-shi” 道士と道人・その語義史 (Tao-shih and tao-jên: Their Semantic History). Tōyō bunka 東洋文化 57: 1-17.

Fung Yu-lan 馮友蘭 (1948): A Short History of Chinese Philosophy. Edited by Derk Bodde. New York: The Macmillan Company.

Gimello, Robert M. (1978): “Random Reflections on the 'Sinicization' of Buddhism”. Society for the Study of Chinese Religions Bulletin 5: 52-89.

Graham, Angus C. (1986): Studies in Chinese Philosophy and Philosophical Literature. Singapore: Institute of East Asian Philosophies, National University of Singapore.

Holcombe, Charles (1994): In the Shadow of the Han: Literati Thought and Society at the Beginning of the Southern Dynasties. Honolulu: University of Hawaii Press.

Holcombe, Charles (1995): "Re-Imagining China: The Chinese Identity Crisis at the Start of the Southern Dynasties Period". Journal of the American Oriental Society 115.1: 1-14.

Hsieh Shu-Wei 謝世維 (2012): “Jung-ho yü chiao-shê: Chung-ku shih-ch’i tê Fo-tao kuan-hsi yenchiu hui-ku” 融合與交涉：中古時期的佛道關係研究回顧 (Syncretism and Interaction: A 
Review of Scholarship on the Relationship between Buddhism and Daoism). Ch'ing-hua Chung-wên hsüeh-pao 清華中文學報 8: 263-299.

Hurvitz, Leon (1960): Review of Japanese Buddhism, by C. Eliot. The Journal of Asian Studies 19.4: 456-457.

Hurvitz, Leon (1965): Review of Buddhism in China: A Historical Survey, by K. Ch'en. Journal of the American Oriental Society 85.3: 448-453.

Hurvitz, Leon N. / Link, Arthur E. (1974). “Three Prajñāpāramitā Prefaces of Tao-An”. In:

Mélanges de Sinologie offerts à Monsieur Paul Demiéville. (Bibliothèque de l'Institut des Hautes Études Chinoises; 20.2). Paris: Institut des Hautes Études Chinoises, 403-470.

Inada, Kenneth K. (1994): “The Challenge of Buddho-Taoist Metaphysics of Experience”. Journal of Chinese Philosophy 21.1: 27-47.

Inada, Kenneth K. (1997): "Buddho-Taoist and Western Metaphysics of the Self”. In: Culture and Self: Philosophical and Religious Perspectives, East and West. Edited by Douglas Allen with Ashok Malhotra. Boulder: Westview Press, 83-93.

Irons, Edward A. (2008): Encyclopedia of Buddhism. (Encyclopedia of World Religions). New York: Facts On File.

James, Jean M. (1989): "Some Iconographic Problems in Early Daoist-Buddhist Sculptures in China". Archives of Asian Art 42: 71-76.

Jones, Lindsay (ed.) (2005): Encyclopedia of Religions: Second Edition. New York: Thomson Gale.

Kamata Shigeo 鎌田茂雄 (1968): Chūgoku Bukkyō shisō-shi kenkyū 中國佛教思想史研究 (Studies in the History of Chinese Buddhist Thought). Tokyo: Shunjūsha 春秋社.

Kim, Young-ho (1985): “Tao-sheng’s Commentary on the Saddharmapundarīka-sūtra: A Study and Translation". PhD dissertation. McMaster University, Hamilton.

Kim, Young-ho (1990): Tao-sheng's Commentary on the Lotus Sūtra: A Study and Translation. (SUNY Series in Buddhist Studies). Albany: State University of New York Press.

Kirkland, Russell (2004): Taoism: The Enduring Tradition. New York/London: Routledge.

Kohn, Livia (1990): “Eternal Life in Taoist Mysticism”. Journal of the American Oriental Society 110.4: 622-640.

Kohn, Livia (1991): Early Chinese Mysticism: Philosophy and Soteriology in the Taoist Tradition. Princeton: Princeton University Press.

Kohn, Livia (ed.) (2000): Daoism Handbook. (Handbook of Oriental Studies, Section 4 China; 14). Leiden/Boston/Köln: Brill.

Lagerwey, John / Lü Pengzhi (eds.) (2010): Early Chinese Religion, Part II: The Period of Division (220-589 AD). (Handbook of Oriental Studies, Section 4 China; 21.2). Leiden/Boston: Brill.

Lai, Whalen W. (1987): “The Earliest Folk Buddhist Religion in China: T'i-wei Po-li Ching and its Historical Significance”. In: Buddhist and Taoist Practice in Medieval Chinese Society: Buddhist and Taoist Studies II. Edited by David W. Chappell. (Asian Studies at Hawaii; 34). Honolulu: University of Hawaii, 11-35.

Lai, Whalen (1990): “The Chan-ch'a ching: Religion and Magic in Medieval China”. In: Chinese Buddhist Apocrypha. Edited by Robert E. Buswell, Jr. (Bibliotheca Indo-Buddhica Series; 114). Honolulu: University of Hawaii Press, 175-206.

Liebenthal, Walter (1948): The Book of Chao: A Translation from the Original Chinese with Introduction, Notes and Appendices. (Monumenta Serica Monograph Series; 13). Peiping: The Catholic University of Peking.

Liebenthal, Walter (1952a): "The Immortality of the Soul in Chinese Thought". Monumenta Nipponica 8.1/2: 327-397. 
Liebenthal, Walter (1952b): "Was ist chinesischer Buddhismus?" Asiatische Studien - Études asiatiques 6.1/4: 116-129.

Liebenthal, Walter (1954): “On Trends in Chinese Thought”. In: Silver Jubilee Volume of the Zinbun-Kagaku-Kenkyusyo, vol. 2. Kyoto: Kyoto University, 262-278.

Liebenthal, Walter (1955): "Chinese Buddhism during the Fourth and Fifth Centuries". Monumenta Nipponica 11.1: 44-83.

Liebenthal, Walter (1956): "The World Conception of Chu Tao-Sheng". Monumenta Nipponica 12.1/2: 65-103.

Liebenthal, Walter (1958): “New Light on the Mahāyāna-Śraddhotpāda Śāstra”. T’oung Pao, Second Series 46.3/5: 155-216.

Liebenthal, Walter (1960): Review of The Buddhist Conquest of China: The Spread and Adaptation of Buddhism in Early Medieval China, by E. Zürcher. Monumenta Serica 19: 527-531.

Liebenthal, Walter (1968): Chao Lun: The Treatises of Seng-Chao: A Translation with Introduction, Notes and Appendices, Second Revised Edition. Hong Kong: Hong Kong University Press.

Liebenthal, Walter (1974): “Ngo 我, Variations of Meaning”. In: Mélanges de Sinologie offerts à Monsieur Paul Demiéville. (Bibliothèque de l'Institut des Hautes Études Chinoises; 20.2). Paris: Institut des Hautes Études Chinoises, 197-203.

Link, Arthur E. (1957): “Shyh Daw-An's Preface to Sangharaksa's Yogācārabhūmi-Sūtra and the Problem of Buddhist-Taoist Terminology in Early Chinese Buddhism". Journal of the American Oriental Society 77.1: 1-14.

Link, Arthur E. (1961): “Cheng-Wu Lun: The Rectification of Unjustified Criticism. To the Memory of Professor F. D. Lessing”. Oriens Extremus 8.2: 136-165.

Link, Arthur E. (1969/1970): “The Taoist Antecedents of Tao-an’s Prajñā Ontology”. History of Religions 9.2/3: 181-215.

Link, Arthur E. / Hurvitz, Leon (1971): “Obituary”. Journal of the American Oriental Society 91.4: 580-582.

Lipman, Jonathan N. (1984): "Ethnicity and Politics in Republican China: The Ma Family Warlords of Gansu”. Modern China 10.3: 285-316.

Liu Yang (2003): "Sakyamuni and Laojun Seated Side By Side: Catching a Glimpse of the Northern Dynasties' Buddhist/Taoist Relationship from a Popular Iconography”. In: Ancient Taoist Art from Shanxi Province. Edited by Susan Y. Y. Lam. Hong Kong: The University of Hong Kong, 54-63.

Martin Rhie, Marylin (2007): Early Buddhist Art of China and Central Asia, vol. 1: Later Han, Three Kingdoms and Western Chin in China and Bactria to Shan-shan in Central Asia. (Handbook of Oriental Studies, Section 4 China; 12.1). Leiden/Boston: Brill.

Maspero, Henri (1934): “Les Origines de la communauté bouddhiste de Lo-Yang”. Journal Asiatique 225: 87-107.

Masuzawa, Tomoko (2005): The Invention of World Religions: Or, How European Universalism Was Preserved in the Language of Pluralism. Chicago/London: The University of Chicago Press.

Mather, Richard B. (1963): “Wang Chin's 'Dhūta Temple Stele Inscription' as an Example of Buddhist Parallel Prose". Journal of the American Oriental Society 83.3: 338-359.

McRae, John R. / Nattier, Jan (eds.) (2012): Buddhism across Boundaries: The Interplay of Indian, Chinese, and Central Asian Source Materials. Special issue of Sino-Platonic Papers 222.

Miller, Alan L. (2000): "Spiritual Accomplishment by Misdirection: Some 'Upāya' Folktales from East Asia”. History of Religions 40.1: 82-108. 
Mollier, Christine (2008): Buddhism and Taoism Face to Face: Scripture, Ritual, and Iconographic Exchange in Medieval China. Honolulu: University of Hawai'i Press.

Mollier, Christine (2010): “Iconizing the Daoist-Buddhist Relationship: Cliff Sculptures in Sichuan during the Reign of Tang Xuanzong”. Daoism: Religion, History and Society 2: 95-133.

Morgan, Carole (1996): “Inscribed Stones: A Note on a Tang and Song Dynasty Burial Rite". T'oung Pao, Second Series 82.4/5: 317-348.

Mu, Soeng (2004): Trust in Mind: The Rebellion of Chinese Zen. Boston: Wisdom Publications.

Mungello, David E. (1985): Curious Land: Jesuit Accommodation and the Origins of Sinology. (Studia Leibnitiana Supplementa; 25). Stuttgart: Franz Steiner.

Mungello, David E. (1999): The Great Encounter of China and the West, 1500-1800. (Critical Issues in History). Lanham: Rowman \& Littlefield.

Mungello, David E. (2005): The Great Encounter of China and the West, 1500-1800. Second Edition. (Critical Issues in History). Lanham: Rowman \& Littlefield.

Mungello, David E. (2009): The Great Encounter of China and the West, 1500-1800. Third Edition. (Critical Issues in History / World and International History). Lanham: Rowman \& Littlefield.

Mungello, David E. (2013): The Great Encounter of China and the West, 1500-1800. Fourth Edition. (Critical Issues in World and International History). Lanham: Rowman \& Littlefield.

Ng, Zhiru (2007): The Making of a Savior Bodhisattva: Dizang in Medieval China. (Studies in East Asian Buddhism; 21). Honolulu: University of Hawai'i Press.

Orzech, Charles D. (2002): “Fang Yankou and Pudu: Translation, Metaphor, and Religious Identity". In: Daoist Identity: History, Lineage, and Ritual. Edited by Livia Kohn and Harold D. Roth. Honolulu: University of Hawai'i Press, 213-234.

Pelliot, Paul (1912): “Autour d'une traduction sanscrite du Tao tö king”. T’oung Pao, Second Series 13.3: 351-430.

Pelliot, Paul (1918/1919): “Meou-tseu ou les Doutes levés”. T’oung Pao, Second Series 19.5: 255-433.

Penny, Benjamin (1996): "Buddhism and Daoism in The 180 Precepts Spoken by Lord Lao". Taoist Resources 6.2: 1-16.

Plassen, Jörg (2015): "The Taoist Voice of the Buddhist Commentaries? Some Remarks on the Influence of the Chuang-tzu on the Use of Language in Buddhist Commentarial Literature". In: Transcending Words: The Language of Religious Contact Between Buddhists, Christians, Jews, and Muslims in Premodern Times. Edited by Görge K. Hasselhoff and Knut Martin Stünkel. Bochum: Winkler, 13-26.

Pregadio, Fabrizio (ed.) (2008): The Encyclopedia of Taoism. London: Routledge.

de Rachewiltz, Igor (1962): “The Hsi-Yu Lu 西遊錄 by Yeh-Lü Ch’u-Ts'ai 耶律楚材”. Monumenta Serica 21: 1-128.

Raz, Gil (2004): The Emergence of Daoism: Creation of Tradition. (Routledge Studies in Taoism). London/New York: Routledge.

Raz, Gil (2014): ““Conversion of the Barbarians' [Huahu 化胡] Discourse as Proto Han Nationalism”. The Medieval History Journal 17.2: 255-294.

Ricci, Mateo (1615). De Christiana expeditione apud Sinas. Edited and translated by Nicholas Trigault. Augsburg.

Robinet, Isabelle (1984): “Notes préliminaires sur quelques antinomies fondamentales entre le bouddhisme et le taoïsme". In: Incontro di Religioni in Asia Tra il III e il X Secolo d.C. Edited by Lionello Lanciotti. Florence: Leo S. Olschki, 217-242.

Robinet, Isabelle (1994): “Primus movens et création récurrente”. Taoist Resources 5.2: 29-69. 
Robinet, Isabelle (1995): “Un, deux, trois: Les différentes modalités de l’Un et sa dynamique”. Cahiers d'Extrême-Asie 8: 175-220.

Robinet, Isabelle (2004): "De quelques effets du bouddhisme sur la problématique taoïste: Aspects de la confrontation du taoïsme au bouddhisme”. In: Religion and Chinese Society. Edited by John Lagerwey. Hong Kong: Chinese University Press / Paris: École Française d'Extrême-Orient, vol. 1, 411-516.

Robinson, Richard H. (1967): Early Mādhyamika in India and China. Madison: The University of Wisconsin Press.

Robinson, Richard H. (1970): The Buddhist Religion: A Historical Introduction. (The Religious Life of Man). Belmont: Dickenson.

Robinson, Richard H. (1977): The Buddhist Religion: A Historical Introduction. Edited by Willard Johnson. (The Religious Life of Man). North Scituate: Duxbury Press.

Robinson, Richard H. (1982): The Buddhist Religion: A Historical Introduction. Edited by Willard L. Johnson, Kathryn Tsai and Shinzen Young. (Religious Life of Man). Belmont: Wadsworth.

Robinson, Richard H. / Johnson, Willard L. (1997): The Buddhist Religion: A Historical Introduction. (Religious Life in History). Belmont: Wadsworth.

Robinson, Richard H. / Johnson, Willard L. / DeGraff, Geoffrey (2005): Buddhist Religions: A Historical Introduction. (Religious Life in History). Belmont: Wadsworth/Thompson.

Robson, James (1995): “The Polymorphous Space of the Southern Marchmount [Nanyue 南获]: An Introduction to Nanyue's Religious History and Preliminary Notes on Buddhist-Daoist Interaction". Cahiers d'Extrême-Asie 8: 221-264.

Robson, James (2009): Power of Place: The Religious Landscape of the Southern Sacred Peak (Nanyue 南获) in Medieval China. (Harvard East Asian Monographs; 316). Cambridge: Harvard University Asia Center.

Robson, James (ed.) (2015): Daoism. (The Norton Anthology of World Religions). New York: W. W. Norton \& Company.

Roth, Harold D. (1974): "The Influence of Taoism upon Chinese Buddhism during the Fourth Century: Case Study: Chih Tun's Understanding of the Prajñāpāramitā”. M.A. dissertation. McMaster University, Hamilton.

Salguero, C. Pierce (2010): "Buddhist Medicine in Medieval China: Disease, Healing, and the Body in Crosscultural Translation (Second to Eighth Centuries C.E.)". PhD dissertation. Johns Hopkins University, Baltimore.

Santangelo, Paolo (2000): "The Cult of Love in Some Texts of Ming and Qing Literature". East and West 50.1/4: 439-499.

Schipper, Kristofer / Verellen, Franciscus (eds.) (2004): The Taoist Canon: A Historical Companion to the Daozang. Chicago/London: The University of Chicago Press.

Schmidt, F. R. A. (2006): "The Textual History of the Materia Medica in the Han Period: A System-Theoretical Reconsideration”. T'oung Pao, Second Series 92.4/5: 293-324.

Seidel, Anna (1969): La Divinisation de Lao tseu dans le taoïsme des Han. (Publications de l'École Française d'Extrême-Orient; 71). Paris.

Seidel, Anna K. (1969/1970): “The Image of the Perfect Ruler in Early Taoist Messianism: Laotzu and Li Hung". History of Religions 9.2/3: 216-247.

Seidel, Anna (1984): "Le Sûtra merveilleux du Ling-pao suprême, traitant de Lao tseu qui convertit les barbares (le manuscrit S. 2081): Contribution à l'étude du Bouddho-Taoïsme des Six Dynasties". In: Contributions aux études de Touen-Houang, vol. 3. Edited by Michel Soymié. (Publications de l’École Française d'Extrême-Orient; 135). Paris, 305-352. 
Seidel, Anna (1989/1990): “Chronicle of Taoist Studies in the West 1950-1990". Cahiers d'Extrême-Asie 5: 223-347.

Seiwert, Hubert (2003): Popular Religious Movements and Heterodox Sects in Chinese History. In collaboration with Ma Xisha. (China Studies; 3). Leiden/Boston: Brill.

Sen, Tansen (1999): “Astronomical Tomb Paintings from Xuanhua: Maṇalas?” Ars Orientalis 29: $29-54$.

Shan-hsi Yao-hsien Yao-wang-shan po-wu-kuan 陝西耀縣藥王山博物館 / Shan-hsi Lin-t’ungshih po-wu-kuan 陝西臨潼市博物館 / Pei-ching Liao-Chin ch'êng-yüan po-wu-kuan 北京遼 金城垣博物館 (eds.) (1996): Pei-ch'ao Fo-tao tsao-hsiang-pei ching-hsüan 北朝佛道造像碑 精選 (Select Buddhist and Taoist Steles with Images of the Northern Dynasties). Tientsin: T'ian-chin ku-chi ch'u-pan-shê 天津古籍出版社.

Sharf, Robert H. (2002a): Coming to Terms with Chinese Buddhism: A Reading of the Treasure Store Treatise. (Studies in East Asian Buddhism; 14). Honolulu: University of Hawai'i Press.

Sharf, Robert H. (2002b): “On Pure Land Buddhism and Ch'an/Pure Land Syncretism in Medieval China”. T'oung Pao, Second Series 88.4/5: 282-331.

Silk, Jonathan A. (2008): "In Memoriam Erik Zürcher (13 September 1928 - 7 February 2008)". Journal of the International Association of Buddhist Studies 31.1/2: 3-22.

Silk, Jonathan A. (ed.) (2013): Buddhism in China: Collected Papers of Erik Zürcher. (Sinica Leidensia; 112). Leiden: Brill.

Sivin, Nathan (1978): “On the Word 'Taoist' as a Source of Perplexity. With Special Reference to the Relations of Science and Religion in Traditional China”. History of Religions 17.3/4: 303-330.

Sivin, Nathan (2010): “Old and New Daoisms". Religious Studies Review 36.1: 31-50.

Sørensen, Henrik H. (1995): "Buddhist Sculptures from the Song Dynasty at Mingshan Temple in Anyue, Sichuan". Artibus Asiae 55.3/4: 281-302.

Sørensen, Henrik H. (1998a): "Perspectives on Buddhism in Dunhuang during the Tang and Five Dynasties Period". In: The Silk Roads: Highways of Culture and Commerce. Edited by Vadime Elisseeff. Paris: UNESCO, 27-48.

Sørensen, Henrik H. (1998b): “The Buddhist Sculptures at Feixian Pavilion in Pujiang, Sichuan". Artibus Asiae 58.1/2: 33-67.

Sørensen, Henrik H. (2004): "Michel Strickmann on Magical Medicine in Medieval China and Elsewhere". History of Religions 43.4: 319-332.

Sørensen, Henrik H. (2013): "Buddho-Daoism in Medieval and Early Pre-Modern China: A Report on Recent Findings Concerning Influences and Shared Religious Practices". The Electronic Journal of East and Central Asian Religions 1: 109-138.

Strickmann, Michel (1978): “A Taoist Confirmation of Liang Wu Ti’s Suppression of Taoism”. Journal of the American Oriental Society 98.4: 467-475.

Strickmann, Michel (1990): “The Consecration Sütra: A Buddhist Book of Spells”. In: Chinese Buddhist Apocrypha. Edited by Robert E. Buswell, Jr. (Bibliotheca Indo-Buddhica Series; 114). Honolulu: University of Hawaii Press, 75-118.

Strickmann, Michel (2002): Chinese Magical Medicine. Edited by Bernard Faure. (Asian Religions and Cultures). Stanford: Stanford University Press.

Strickmann, Michel (2005): Chinese Poetry and Prophecy: The Written Oracle in East Asia. Edited by Bernard Faure. (Asian Religions and Cultures). Stanford: Stanford University Press.

Takakusu Junjirō 高楠順次郎 / Watanabe Kaikyoku 渡邊海旭 (eds.) (1924-1934): Taishō shinshū daizōkyō 大正新修大藏經 (Revised Tripitaka of the Taishō [Era]). Tokyo: Taishō issaikyō kankōkai 大正一切經刊行會. 
T'ang Yung-t'ung 湯用娅 (1938): Han Wei liang-Chin nan-pei-ch'ao Fo-chiao-shih 漢魏兩晉南北 朝佛教史 (History of Buddhism in the Han, Wei, two Chin, and Southern and Northern Dynasties). Changsha: Shang-wu yin-shu-kuan 商務印書館.

Teiser, Stephen F. (1988): The Ghost Festival in Medieval China. Princeton: Princeton University Press.

Teiser, Stephen F. (1994): “In Memoriam Anna K. Seidel (1938-1991)”. Asia Major, Third Series 7.1: 1-4.

Teiser, Stephen F. / Verellen, Franciscus (2010a): “Buddhism, Daoism, and Chinese Religion”. Cahiers d'Extrême-Asie 20: 1-12.

Teiser, Stephen F. / Verellen, Franciscus (2010b): “To Our Readers”. Cahiers d'Extrême-Asie 20: iii-iv.

Thompson, John M. (2008): Understanding Prajñā: Sengzhao's "Wild Words" and the Search for Wisdom. (American University Studies, 7 Theology and Religion; 256). New York: Peter Lang.

Tsukamoto Zenryū 塚本善隆 (1979) [1968]: Chūgoku Bukkyō tsūshi (dai ikkan) 中國佛教通史 (第 一巻) (General History of Chinese Buddhism). Tokyo: Shunjūsha 春秋社.

Tsukamoto Zenryū (1985): A History of Early Chinese Buddhism: From Its Introduction to the Death of Hui-yüan. Translated by Leon Hurvitz. Tokyo/New York: Kodansha International.

Verellen, Franciscus (1992): “'Evidential Miracles in Support of Taoism': The Inversion of a Buddhist Apologetic Tradition in Late Tang China”. T'oung Pao, Second Series 78.4/5: 217-263.

Verellen, Franciscus (1995): “Taoism”. The Journal of Asian Studies 54.2: 322-346.

Verellen, Franciscus (2000): "Société et religion dans la Chine médiévale: Le regard de Du Guangting 杜光庭 (850-933) sur son époque”. Bulletin de l'École Française d'ExtrêmeOrient 87.1: 267-282.

Verellen, Franciscus (2011): Review of Power of Place: The Religious Landscape of the Southern Sacred Peak (Nanyue 南获) in Medieval China, by J. Robson. Harvard Journal of Asiatic Studies 71.1: 204-208.

Welch, Holmes H. (1969/1970): “The Bellagio Conference on Taoist Studies”. History of Religions 9.2/3: 107-136.

Wong, Dorothy C. (2004): Chinese Steles: Pre-Buddhist and Buddhist Use of a Symbolic Form. Honolulu: University of Hawai'i Press.

Wright, Arthur F. (1957): "Buddhism and Chinese Culture: Phases of Interaction”. The Journal of Asian Studies 17.1: 17-42.

Wright, Arthur F. (1959): Buddhism in Chinese History. Stanford: Stanford University Press.

Wu, Hung (1986): "Buddhist Elements in Early Chinese Art (2nd and 3rd Centuries A.D.)”. Artibus Asiae 47.3/4: 263-352.

Xiong, Victor Cunrui (ed.) (2009): Historical Dictionary of Medieval China. (Historical Dictionaries of Ancient Civilizations and Historical Eras; 19). Lanham: The Scarecrow Press. Yoshioka Yoshitoyo 吉岡義豐 (1959): Dōkyō to Bukkyō (dai ichi) 道教と佛教 (第一) (Taoism and Buddhism I). Tokyo: Nihon gakujutsu shinkōkai 日本學術振興會.

Yu, David C. (1971): “A Buddho-Taoist Sect in Modern China”. History of Religions 11.1: 157-160.

Yu, David C. (1974): "Skill-in-Means and the Buddhism of Tao-Sheng: A Study of a Chinese Reaction to Mahāyāna of the Fifth Century”. Philosophy East and West 24.4: 413-427.

Zhang, Xunliao (2010): “Daoist Stelae of the Northern Dynasties”. In: Early Chinese Religion, Part II: The Period of Division (220-589 AD). Edited by John Lagerwey and Lü Pengzhi. (Handbook of Oriental Studies, Section 4 China; 21.2). Leiden/Boston: Brill, 437-543. 
Zürcher, Erik (1959): The Buddhist Conquest of China: The Spread and Adaptation of Buddhism in Early Medieval China. (Sinica Leidensia; 11). Leiden: E. J. Brill.

Zürcher, Erik (1980): "Buddhist Influence on Early Taoism: A Survey of Scriptural Evidence". T'oung Pao, Second Series 66.1/3: 84-147.

Zürcher, Erik (1981): “Eschatology and Messianism in Early Chinese Buddhism”. In: Leyden Studies in Sinology: Papers Presented at the Conference Held in Celebration of the Fiftieth Anniversary of the Sinological Institute of Leyden University, December 8-12, 1980. Edited by Wilt L. Idema. (Sinica Leidensia; 15). Leiden: E. J. Brill, 34-56.

Zürcher, Erik (1982a): "Perspectives in the Study of Chinese Buddhism”. Journal of the Royal Asiatic Society of Great Britain and Ireland 2: 161-176.

Zürcher, Erik (1982b): “'Prince Moonlight': Messianism and Eschatology in Early Medieval Chinese Buddhism". T'oung Pao, Second Series 68.1/3: 1-75.

Zürcher, Erik (1990): "Han Buddhism and the Western Region”. In: Thought and Law in Qin and Han China: Studies Dedicated to Anthony Hulsewé on the Occasion of his Eightieth Birthday. Edited by Wilt L. Idema and Erik Zürcher. (Sinica Leidensia; 24). Leiden: E. J. Brill, 158-182.

Zürcher, Erik (1999): “Buddhism across Boundaries: The Foreign Input”. In: Collection of Essays 1993: Buddhism across Boundaries, Chinese Buddhism and the Western Regions. Taipei: Foguang Shan Foundation for Buddhist \& Culture Education, 1-59.

Zürcher, Erik (2007): The Buddhist Conquest of China: The Spread and Adaptation of Buddhism in Early Medieval China. Third Edition with a Foreword by Stephen F. Teiser. (Sinica Leidensia; 11). Leiden: Brill.

Article Note: Research for this paper was conducted during a 12-month fellowship at the Käte Hamburger Kolleg "Dynamiken der Religionsgeschichte zwischen Asien und Europa", Ruhr-Universität Bochum, Germany (2014-2015). 